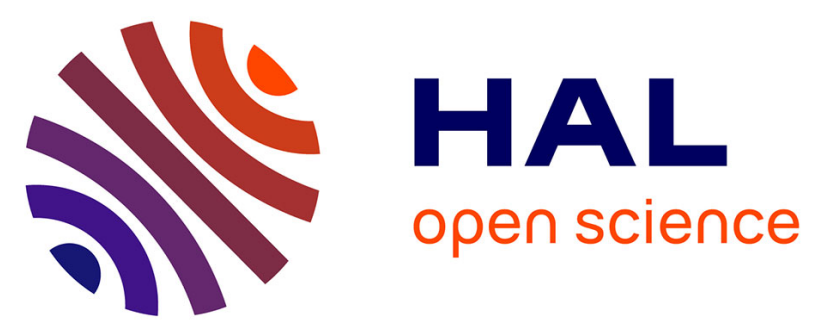

\title{
Oxidation resistance of Ti 3 AlC 2 and Ti 3 Al 0.8 Sn 0.2 C 2 MAX phases: A comparison
}

Elodie Drouelle, Véronique Brunet, Jonathan Cormier, Patrick Villechaise, Pierre Sallot, Foad Naimi, Frederic Bernard, Sylvain Dubois

\section{- To cite this version:}

Elodie Drouelle, Véronique Brunet, Jonathan Cormier, Patrick Villechaise, Pierre Sallot, et al.. Oxidation resistance of $\mathrm{Ti} 3 \mathrm{AlC} 2$ and $\mathrm{Ti} 3 \mathrm{Al} 0.8 \mathrm{Sn} 0.2 \mathrm{C} 2 \mathrm{MAX}$ phases: A comparison. Journal of the American Ceramic Society, 2019, 103 (2), pp.1270-1280. 10.1111/jace.16780 . hal-03100621

\section{HAL Id: hal-03100621 \\ https://hal.science/hal-03100621}

Submitted on 6 Jan 2021

HAL is a multi-disciplinary open access archive for the deposit and dissemination of scientific research documents, whether they are published or not. The documents may come from teaching and research institutions in France or abroad, or from public or private research centers.
L'archive ouverte pluridisciplinaire HAL, est destinée au dépôt et à la diffusion de documents scientifiques de niveau recherche, publiés ou non, émanant des établissements d'enseignement et de recherche français ou étrangers, des laboratoires publics ou privés. 


\title{
Oxidation resistance of $\mathrm{Ti}_{3} \mathrm{AlC}_{2}$ and $\mathrm{Ti}_{3} \mathrm{Al}_{0.8} \mathrm{Sn}_{0.2} \mathrm{C}_{2} \mathrm{MAX}$ phases: a comparison
}

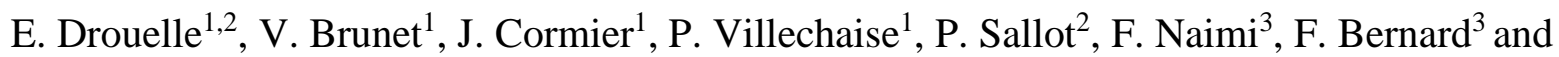 \\ S. Dubois ${ }^{1}$ \\ ${ }^{1}$ Institut PPRIME, CNRS/Université de Poitiers/ENSMA, UPR 3346 CNRS, Boulevard M. et \\ P. Curie, BP 30179, 86962 Chasseneuil du Poitou-Futuroscope Cedex, France \\ ${ }^{2}$ Safran Tech, 1 rue Geneviève Aubé, CS 80112, 78772 Magny les hameaux Cedex, France \\ 3 Laboratoire Interdisciplinaire Carnot de Bourgogne, UMR 6303 CNRS-Université de \\ Bourgogne Franche-Comté, 9 Av. Alain Savary, BP 47870, 21078 DIJON Cedex, France
}

\begin{abstract}
$\mathrm{Ti}_{3} \mathrm{AlC}_{2}$ and $\mathrm{Ti}_{3} \mathrm{Al}_{0.8} \mathrm{Sn}_{0.2} \mathrm{C}_{2}$ MAX phase powders are densified using Spark Plasma Sintering technique to obtain dense bulk materials. Oxidation tests are then performed over the temperature range $800-1000^{\circ} \mathrm{C}$ under synthetic air on the two different materials in order to compare their oxidation resistance. It is demonstrated that, in the case of the $\mathrm{Ti}_{3} \mathrm{Al}_{0.8} \mathrm{Sn}_{0.2} \mathrm{C}_{2}$ solid solution, the oxide layers consist in $\mathrm{TiO}_{2}, \mathrm{Al}_{2} \mathrm{O}_{3}$ and $\mathrm{SnO}_{2}$. The presence of $\mathrm{Sn}$ atoms in the A planes of the solid solution leads to an easy diffusion of Sn out of the MAX phase which promote the formation of the non-protective and fast growing $\mathrm{SnO}_{2}$ oxide. Moreover, the small $\mathrm{Al} / \mathrm{Ti}$ atom's ratio promotes the growth of a non-protective rutile- $\mathrm{TiO}_{2}$ scale as well. In the case of the $\mathrm{Ti}_{3} \mathrm{AlC}_{2}$ MAX phase, the oxide layer consists in a protective alumina scale; a few $\mathrm{TiO}_{2}$ grains being observed on the top of the $\mathrm{Al}_{2} \mathrm{O}_{3}$ layer. The parabolic oxidation rate constants are about 3 orders of magnitude smaller for $\mathrm{Ti}_{3} \mathrm{AlC}_{2}$ compared to $\mathrm{Ti}_{3} \mathrm{Al}_{0.8} \mathrm{Sn}_{0.2} \mathrm{C}_{2}$.
\end{abstract}




\section{$\underline{\text { I - Introduction }}$}

MAX phases are a family of nanolaminated ternary nitrides and carbides, with the general formula $\mathrm{M}_{\mathrm{n}+1} \mathrm{AX} \mathrm{n}$ ( $\mathrm{n}=1$ to 3 ), where $\mathrm{M}$ is a transition metal, $\mathrm{A}$ is an element from group $\mathrm{A}$, and $\mathrm{X}$ is either carbon or nitrogen ${ }^{1}$. Depending on the $\mathrm{n}$ value, they are now often named $413(n=3)$, $312(n=2)$ or $211(n=1)$ MAX phase. These compounds were first discovered in the $1960 \mathrm{~s}^{2-4}$, however, they were revived in 1995 when Barsoum et al. discovered that they exhibit unique physical and chemical properties ${ }^{5}$. The three compounds crystallize in a hexagonal P63/mmc lattice characterized by $\mathrm{M}_{6} \mathrm{X}$ octahedra separated by $\mathrm{A}$ atomic layers. Their unique structure, combining both strong covalent M-X bonds and weaker M-A bonds, confers to MAX phases properties of both classes of materials. Like ceramics, they are stiff, lightweight, chemically stable and oxidation resistant. Like metals, they are relatively soft, machinable, resistant to thermal shock and they exhibit good electric and thermal conductivity as well as good damage tolerance ${ }^{5-7}$.

Among the 312 phases, $\mathrm{Ti}_{3} \mathrm{AlC}_{2}$ and its solid solution have attractive properties. $\mathrm{Ti}_{3} \mathrm{AlC}_{2}$ possesses quite remarkable properties such as low density $\left(4.25 \mathrm{~g} / \mathrm{cm}^{3}\right)$, high Young's modulus (297 GPa), high strength at high temperature, self-lubrication, good machinability, high thermal and electrical conductivity $e t c^{8-10}$. Moreover, Alumina-forming MAX phases are well-known for their excellent oxidation resistance ${ }^{11-19 b}$, rivaling many metallic $\mathrm{NiAl}, \mathrm{NiCrAl}$, and $\mathrm{FeCrAl}$ counterparts ${ }^{\mathrm{PhD} \text { thesis Elodie }}$ and with upper temperature capability possible to $\sim 1400{ }^{\circ} \mathrm{C}$. Hence, these remarkable properties make $\mathrm{Ti}_{3} \mathrm{AlC}_{2}$ a promising material for various applications. However, before they can be used it is imperative to be able to predict the oxide thicknesses that would form after long times at elevated temperatures. This, in turn implies that the oxidation kinetics be well understood and documented. Pietzka and Schuster first synthesized bulk polycrystalline $\mathrm{Ti}_{3} \mathrm{AlC}_{2}$ by sintering cold-compacted powder mixtures of $\mathrm{Ti}, \mathrm{TiAl}, \mathrm{Al}_{4} \mathrm{C}_{3}$ and $\mathrm{C}$ at $1573 \mathrm{~K}$ under pure hydrogen for $20 \mathrm{~h}^{20}$. Tzenov and Barsoum prepared bulk 
polycrystalline $\mathrm{Ti}_{3} \mathrm{AlC}_{2}$ (4 vol.\% $\mathrm{Al}_{2} \mathrm{O}_{3}$ as impurity in the sample) by reactive Hot Isostatic Pressing (HIP) at $70 \mathrm{MPa}$ and $1400^{\circ} \mathrm{C}$ for $16 \mathrm{~h}$ using a mixture of $\mathrm{Ti}, \mathrm{C}$ and $\mathrm{Al}_{4} \mathrm{C}_{3}$ powders and investigated some properties of the as-synthesized samples ${ }^{8}$. Wang and Zhou produced fully dense $\mathrm{Ti}_{3} \mathrm{AlC}_{2}$ using a solid-liquid reaction synthesis and simultaneous in situ hot pressing process using a mixture of $\mathrm{Ti}, \mathrm{Al}$, and graphite as starting powders ${ }^{21}$. Zhou et al. fabricated $\mathrm{Ti}_{3} \mathrm{AlC}_{2}$ by Self-propagating High-temperature Synthesis (SHS) from elemental Ti, $\mathrm{Al}$ and C, followed by a densification step using the Spark-Plasma Sintering (SPS) method ${ }^{22}$. However, the purity of the $\mathrm{Ti}_{3} \mathrm{AlC}_{2}$ was not easy to control, because of the thermal explosion that occurred among the elemental raw materials. Zhu et al. synthesized $\mathrm{Ti}_{3} \mathrm{AlC}_{2}$ by hot pressing $\mathrm{TiC}, \mathrm{Ti}$, and Al powders at $1573-1673 \mathrm{~K}$ for $2 \mathrm{~h}$ under a pressure of $30 \mathrm{MPa}^{23}$. Finally, a variety of methods are implemented to prepare $\mathrm{Ti}_{3} \mathrm{AlC}_{2}$ bulk samples or $\mathrm{Ti}_{3} \mathrm{AlC}_{2}$ powder samples. Nevertheless, it is difficult to obtain a single-phase $\mathrm{Ti}_{3} \mathrm{AlC}_{2}$ material due to the narrow phase domain in the Ti$\mathrm{Al}-\mathrm{C}$ phase diagram. Impurities such as $\mathrm{TiC}, \mathrm{Ti}_{\mathrm{x}} \mathrm{Al}_{\mathrm{y}}$ intermetallics, $\mathrm{Al}_{2} \mathrm{O}_{3}$ or the $211 \mathrm{MAX}$ phase $\left(\mathrm{Ti}_{2} \mathrm{AlC}\right)$ are commonly detected in the end-products ${ }^{10,24-30}$. Especially, the presence of TiC invariably deteriorates the high electrical conductivity ${ }^{7}$, the oxidation resistance ${ }^{18}$ and some other properties of $\mathrm{Ti}_{3} \mathrm{AlC}_{2}$. Thus, several sintering additives such as $\mathrm{Si}^{31}, \mathrm{Sn}^{32,33}$ and $\mathrm{B}_{2} \mathrm{O}_{3}{ }^{34}$ were introduced into Ti-Al-C system to avoid impurity formation and to get the $\mathrm{Ti}_{3} \mathrm{AlC}_{2}$ single phase. The former research work by Ai et al. ${ }^{32}$ and Li et al. ${ }^{33}$ has proved that $\mathrm{Sn}$ is an efficient additive to inhibit the $\mathrm{TiC}$ impurity formation. A nearly pure $\mathrm{Ti}_{3} \mathrm{AlC}_{2}$ was thus obtained in a relative wide temperature range by pressureless sintering $3 \mathrm{Ti}+\mathrm{Al}+1.8 \mathrm{C}$ with $0.2 \mathrm{~mol}$ of added Sn. Ai et al. ${ }^{32}$ also detected some $\mathrm{Sn}$ in the final products by Energy Dispersive X-ray Spectrometry (EDXS) and reported more Sn distributed in the grain boundary rather than in the $\mathrm{Ti}_{3} \mathrm{AlC}_{2}$ structure. Bei et al. have studied, in details, the synthesis of $\mathrm{Ti}_{3} \mathrm{Al}_{1-\mathrm{x}} \mathrm{Sn}_{\mathrm{x}} \mathrm{C}_{2}$ solid solution by Hot Isostatic Pressing ${ }^{33 b, 33 c}$. 
The first paper describing the oxidation behaviour of $\mathrm{Ti}_{n+1} \mathrm{AlC}_{\mathrm{n}}$ has been published in $2001^{14}$. Since that date, the high-temperature oxidation behavior of $\mathrm{Ti}_{3} \mathrm{AlC}_{2}$ has been extensively studied ${ }^{11-19 c}$; a review paper can also be found ${ }^{15}$. However, to our knowledge, the oxidation behaviour of $\mathrm{Ti}_{3} \mathrm{Al}_{(1-\mathrm{x})} \mathrm{Sn}_{\mathrm{x}} \mathrm{C}_{2}$ solid solution has not been studied. Barsoum studied the oxidation behavior of $\mathrm{Ti}_{3} \mathrm{AlC}_{2}$ at $1073-1373 \mathrm{~K}$ in air for exposure times up to $100 \mathrm{~h}^{8,14}$. The oxide layers mainly consist in a rutile-based solid solution, $\left(\mathrm{Ti}_{1-\mathrm{y}} \mathrm{Al}_{\mathrm{y}}\right) \mathrm{O}_{2-\mathrm{y} / 2}$ with $\mathrm{y}<0.05$, and some $\mathrm{Al}_{2} \mathrm{O}_{3}$. Barsoum's specimens formed thick and highly striated oxide layers during hightemperature oxidation. Barsoum further explained that the subjection of the $\left(\mathrm{Ti}_{1-\mathrm{y}} \mathrm{Al}_{\mathrm{y}}\right) \mathrm{O}_{1-\mathrm{y} / 2}$ layer to an oxygen chemical potential gradient resulted in its demixing, with the dissolution of the $\mathrm{Al}^{3+}$ into the rutile at a lower oxygen partial pressure and its precipitation as $\mathrm{Al}_{2} \mathrm{O}_{3}$ at a higher partial pressure. When the demixing occurred extensively, the resulting microstructure became highly striated, consisting of three layers, an $\mathrm{Al}_{2} \mathrm{O}_{3}$-rich layer, an $\left(\mathrm{Ti}_{1-\mathrm{y}} \mathrm{Al}_{\mathrm{y}}\right) \mathrm{O}_{1-\mathrm{y} / 2 \text {-rich }}$ layer, and a porous layer, which repeated numerous times ${ }^{8}$. The $\mathrm{C}$ atoms were presumed to diffuse through the reaction layers and oxidize. The rate-limiting step was thought to be the diffusion of oxygen and/or $\mathrm{Ti}^{8}$. Wang and Zhou studied $\mathrm{Ti}_{3} \mathrm{AlC}_{2}$ oxidation behavior at $1273-$ $1673 \mathrm{~K}$ in air for exposure times up to $20 \mathrm{~h}^{11}$. The results indicated that $\mathrm{Ti}_{3} \mathrm{AlC}_{2}$ oxidized following parabolic kinetics, and its excellent oxidation resistance was attributed to the formation of an adherent, continuous inner $\mathrm{Al}_{2} \mathrm{O}_{3}$ layer, which formed below an outer $\mathrm{TiO}_{2}$ layer. It is proposed that the inner $\mathrm{Al}_{2} \mathrm{O}_{3}$ layer might has been formed by the inward diffusion of oxygen through the outer $\mathrm{TiO}_{2}$ layer, and the outer $\mathrm{TiO}_{2}$ layer by the outward diffusion of Ti. In 2006, Lee and Park ${ }^{19 b}$ reported that the oxidation kinetics can lead either to the predominant formation of $\mathrm{TiO}_{2}$ layers or to the predominant formation of $\alpha-\mathrm{Al}_{2} \mathrm{O}_{3}$ layers. Needless to add, the samples that formed an $\mathrm{Al}_{2} \mathrm{O}_{3}$ layer were quite oxidation resistant. In such a case, an inner, thick $\mathrm{Al}_{2} \mathrm{O}_{3}$ barrier layer formed below the outer, thin $\mathrm{TiO}_{2}$ layer ${ }^{11,15,17,19 b}$. However, when the oxide layers formed were $\mathrm{TiO}_{2}$-based, the resulting oxidation resistance 
was poor. In such a case, either alternating (thick $\mathrm{TiO}_{2}$ layer)/(thin $\mathrm{Al}_{2} \mathrm{O}_{3}$ layers) or a thin, intermediate $\mathrm{Al}_{2} \mathrm{O}_{3}$ barrier layer plus a thick, $\left(\mathrm{TiO}_{2}+\mathrm{Al}_{2} \mathrm{O}_{3}\right)$-mixed layer formed ${ }^{14,15,19 \mathrm{~b}}$. In all cases, the outermost scale is consistently composed of $\mathrm{TiO}_{2}{ }^{14,15,19 \mathrm{~b}}$. It has been demonstrated that the thin $\mathrm{Al}_{2} \mathrm{O}_{3}$ layer forms first due to the fast diffusion of $\mathrm{Al}$ in the basal plane of the MAX phase ${ }^{19 \mathrm{~b}-19 \mathrm{e}}$. The $\mathrm{TiO}_{2}$ layers that forms on top of the $\mathrm{Al}_{2} \mathrm{O}_{3}$ layer results from an outward diffusion of $\mathrm{Ti}$ atoms through the grain boundary of preformed $\mathrm{Al}_{2} \mathrm{O}_{3}{ }^{19 \mathrm{~b}, 19 \mathrm{~d}}$. Finally, the $\left(\mathrm{TiO}_{2}+\mathrm{Al}_{2} \mathrm{O}_{3}\right)$-mixed layer results from an inward diffusion of oxygen ${ }^{19 \mathrm{~b}}$.

In this context, the present study takes the advantage of the comparison of $\mathrm{Ti}_{3} \mathrm{AlC}_{2}$ and $\mathrm{Ti}_{3} \mathrm{Al}_{0.8} \mathrm{Sn}_{0.2} \mathrm{C}_{2}$ solid solution synthesized by SPS in order to better understand the role of $\mathrm{Sn}$ substitution on A sites on oxidation properties. Hence, oxidation products, kinetics and resistance of the $\mathrm{Ti}_{3} \mathrm{AlC}_{2}$ and $\mathrm{Ti}_{3} \mathrm{Al}_{0.8} \mathrm{Sn}_{0.2} \mathrm{C}_{2}$ compounds are compared to finally conclude on the influence of the Al substitution by Sn on the oxidation resistance of 312 MAX phases. 


\section{$\underline{\text { II- Experimental procedures }}$}

$\mathrm{Ti}_{3} \mathrm{AlC}_{2}$ samples were synthesized by powder metallurgy. Titanium, aluminum and titanium carbide powders were blended in quasi stoichiometric proportions (i.e. 1.9TiC-1.05AlTi) for $20 \mathrm{~min}$ in a Turbula ${ }^{\circledR}$ mixer. The reactant powder mixture is encapsulated in a glass container in vacuum and thus, sintered in argon atmosphere for $2 \mathrm{~h}$ at $1450^{\circ} \mathrm{C}$ to produce porous $\mathrm{Ti}_{3} \mathrm{AlC}_{2}$ bulk material which is subsequently crushed into powder. After the $\mathrm{Ti}_{3} \mathrm{AlC}_{2}$ synthesis, XRD analysis was systematically performed; the corresponding X-Ray diffractograms (not shown) do not show any impurity at the $\mathrm{X}$-Ray scale. The same is true for the $\mathrm{Ti}_{3} \mathrm{Al}_{0.8} \mathrm{Sn}_{0.2} \mathrm{C}_{2}$ commercial solid solution provided by Jinghe Technology Co., Ltd. Beijing. For comparison, this in-house $\mathrm{Ti}_{3} \mathrm{AlC}_{2}$ powder and a commercial $\mathrm{Ti}_{3} \mathrm{Al}_{0.8} \mathrm{Sn}_{0.2} \mathrm{C}_{2}$ batch were densified by Spark Plasma Sintering (SPS, model HPD 125 FCT system installed in a "Flash Sintering platform" within the University of Burgundy) in vacuum at $1315^{\circ} \mathrm{C}$ for $2 \mathrm{~min}$ at a pressure of $75 \mathrm{MPa}$ with a cooling rate adjusted to $70^{\circ} \mathrm{C} / \mathrm{min}$. The sample diameters were $60 \mathrm{~mm}$.

X-Ray Diffraction (XRD) analyses were performed using a Bruker D501 diffractometer with $\mathrm{Cu}-\mathrm{K} \alpha$ radiation in order to identify the impurities contained in bulk materials and also to identify the oxidation products. XRD data were refined using the MAUD software in order to extract the composition of the different $\mathrm{Ti}_{3} \mathrm{AlC}_{2}$ and $\mathrm{Ti}_{3} \mathrm{Al}_{0.8} \mathrm{Sn}_{0.2} \mathrm{C}_{2}$ samples ${ }^{35}$. After an appropriate mechanical polishing of the SPSed samples, Polarized Light Microscopy method (PLM, Zeiss Imager Vario Z2) was used to investigate the grain size distribution and to quantify the amount of the different impurities. The porosity content was measured using the Archimedes method.

The microstructure of the $\mathrm{Ti}_{3} \mathrm{AlC}_{2}$ and $\mathrm{Ti}_{3} \mathrm{Al}_{0.8} \mathrm{Sn}_{0.2} \mathrm{C}_{2}$ bulk samples (grain size, distribution of porosity, location and composition of secondary phases) and the one of the oxidation products (morphology and composition of the oxide scale) were examined by Scanning Electron Microscopy using a high resolution field-emission gun scanning electron 
microscope (FESEM, Jeol 7001F-TTLS) coupled with energy-dispersive X-ray spectrometer (EDXS, Oxford Energy) for chemical analyses.

Cylindrical (diameter: $6-10 \mathrm{~mm}$, thickness: $0.5-2 \mathrm{~mm})$ and parallelepiped $(2.5 \times 2.5 \times 3$ $\mathrm{mm}^{3}$ ) specimens were polished with $\mathrm{SiC}$ paper up to 2400 grade prior to oxidation tests. Oxidation tests were performed under isothermal conditions over the temperature range 800$1000^{\circ} \mathrm{C}$. The oxidation kinetics of $\mathrm{Ti}_{3} \mathrm{AlC}_{2}$ and $\mathrm{Ti}_{3} \mathrm{Al}_{0.8} \mathrm{Sn}_{0.2} \mathrm{C}_{2} \mathrm{MAX}$ phase compounds were measured using isothermal thermogravimetric tests (Setaram Setsys TG16 and Setaram Setsys Evolution) under synthetic dry air for 30 to 100h. Heating and cooling were performed in argon atmosphere.

\section{$\underline{\text { III - Results and discussion }}$}

\section{$\underline{\text { III-1- } \mathrm{Ti}_{3} \mathrm{AlC}} \mathrm{C}_{2}$ and $\mathrm{Ti}_{3} \mathrm{Al}_{0.8} \mathrm{Sn}_{0.2} \mathrm{C}_{2}$ microstructural characterization}

Figure 1 shows the XRD patterns obtained on the $\mathrm{Ti}_{3} \mathrm{AlC}_{2}$ and $\mathrm{Ti}_{3} \mathrm{Al}_{0.8} \mathrm{Sn}_{0.2} \mathrm{C}_{2}$ bulk samples. Rietveld refinement of the XRD data underlines the presence of about 0.1-0.2 wt. \% of titanium carbide in the sintered samples. As shown in figure 1, the X-ray peaks of the solid solution are displaced to smaller angles reflecting an increase of the cell parameters. Rietveld

refinement allows determining the cell parameters $(\mathrm{a}=3.0747(6) \AA$ and $\mathrm{c}=18.5720(5) \AA)$ and $\left(\mathrm{a}=3.0841(6) \AA\right.$ and $\mathrm{c}=18.5865(5) \AA$ ) of the $\mathrm{Ti}_{3} \mathrm{AlC}_{2}$ and $\mathrm{Ti}_{3} \mathrm{Al}_{0.8} \mathrm{Sn}_{0.2} \mathrm{C}_{2}$ compounds respectively. The cell parameters of $\mathrm{Ti}_{3} \mathrm{AlC}_{2}$ and of $\mathrm{Ti}_{3} \mathrm{Al}_{0.8} \mathrm{Sn}_{0.2} \mathrm{C}_{2}$ are in very good agreement with the ones published previously ${ }^{20,33 b, 33 d, 33 e}$.

Figure 2 shows back-scaterred SEM micrographs obtained on the $\mathrm{Ti}_{3} \mathrm{AlC}_{2}$ and $\mathrm{Ti}_{3} \mathrm{Al}_{0.8} \mathrm{Sn}_{0.2} \mathrm{C}_{2}$ SPSed samples. Figure 2 and EDXS analyses allow demonstrating the presence of small amount of $\mathrm{Ti}_{\mathrm{x}} \mathrm{Al}_{\mathrm{y}}$ intermetallics (variable $\mathrm{x}$ and $\mathrm{y}$ contents) and $\mathrm{Al}_{2} \mathrm{O}_{3}$ grains randomly distributed at $\mathrm{Ti}_{3} \mathrm{AlC}_{2}$ and $\mathrm{Ti}_{3} \mathrm{Al}_{0.8} \mathrm{Sn}_{0.2} \mathrm{C}_{2}$ grain boundaries. EDXS analyses enable to confirm the presence of TiC. $\mathrm{Al}_{2} \mathrm{O}_{3}$ and $\mathrm{Ti}_{\mathrm{x}} \mathrm{Al}_{\mathrm{y}}$ impurities are either formed during the powder synthesis 
or during the densification by SPS. However, TiC is very likely formed during the SPS densification as its presence was not detected by XRD after the powder synthesis. $\mathrm{As}^{\mathrm{Al}_{2} \mathrm{O}_{3}}$ displays rather weak XRD lines and as some of the alumina may be amorphous, this alumina phase is not detected using XRD although the amount of $\mathrm{Al}_{2} \mathrm{O}_{3}$ is in the same range as the one of TiC. In the same vein, $\mathrm{Ti}_{\mathrm{x}} \mathrm{Al}_{\mathrm{y}}$ may not be detected as a consequence of the large composition range of the formed $\mathrm{Ti}_{\mathrm{x}} \mathrm{Al}_{\mathrm{y}}$ and also as a result of the superimposition of the main $\mathrm{Ti}_{\mathrm{x}} \mathrm{Al}_{\mathrm{y}}$ peaks with the ones of the MAX phase. Using the light microscopy protocol, one can notice that:

- The amount of pores is about the same for both materials (in the range 1-2 vol.\% in $\mathrm{Ti}_{3} \mathrm{AlC}_{2}$ and $1-3$ vol. $\%$ in $\left.\mathrm{Ti}_{3} \mathrm{Al}_{0.8} \mathrm{Sn}_{0.2} \mathrm{C}_{2}\right)$

- The amount of $\mathrm{Al}_{2} \mathrm{O}_{3}$ is slightly larger in $\mathrm{Ti}_{3} \mathrm{AlC}_{2}$ (in the range 1.2-1.4 vol.\%) compared to $\mathrm{Ti}_{3} \mathrm{Al}_{0.8} \mathrm{Sn}_{0.2} \mathrm{C}_{2}$ (in the range 0-1.3 vol.\%).

- The amount of $\mathrm{Ti}_{\mathrm{x}} \mathrm{Al}_{\mathrm{y}}$ intermetallics is slightly larger in $\mathrm{Ti}_{3} \mathrm{Al}_{0.8} \mathrm{Sn}_{0.2} \mathrm{C}_{2}$ (in the range 1-5 vol.\%) compared to $\mathrm{Ti}_{3} \mathrm{AlC}_{2}(0.2-1$ vol.\%).

- The grain size, as determined from the PLM method and from Electron Backscattered Diffraction, is $4.4 \mu \mathrm{m}$ for the $\mathrm{Ti}_{3} \mathrm{Al}_{0.8} \mathrm{Sn}_{0.2} \mathrm{C}_{2}$ grains and $3.9 \mu \mathrm{m}$ for the $\mathrm{Ti}_{3} \mathrm{AlC}_{2}$ ones (mean equivalent diameter).

\section{III-2- Oxidation behaviors}

Figure 3 shows the weight gain per surface area recorded as a function of the oxidation time and at different temperatures on the $\mathrm{Ti}_{3} \mathrm{AlC}_{2}$ and on the $\mathrm{Ti}_{3} \mathrm{Al}_{0.8} \mathrm{Sn}_{0.2} \mathrm{C}_{2}$ solid solution. One can notice that the weight gain is very high for the $\mathrm{Ti}_{3} \mathrm{Al}_{0.8} \mathrm{Sn}_{0.2} \mathrm{C}_{2}$ solid solution compared to the one obtained for $\mathrm{Ti}_{3} \mathrm{AlC}_{2}$. As an example, it is about $3 \mathrm{~g} \cdot \mathrm{m}^{-2}$ for $\mathrm{Ti}_{3} \mathrm{AlC}_{2}$ after $30 \mathrm{~h}$ at $1000^{\circ} \mathrm{C}$ and around 300 g.m $\mathrm{m}^{-2}$ for the solid solution.

After a transient stage, the oxidation kinetics, $\Delta \mathrm{m} / \mathrm{A}=\mathrm{f}(\mathrm{t})$, can be described either by a parabolic or by a cubic law as shown for the $\mathrm{Ti}_{3} \mathrm{AlC}_{2}$ SPSed samples in figure 4 . It has to be noticed that M. W. Barsoum et al. and J. L. Smialek have shown that a cubic law better fits the experimental 
results than a parabolic one ${ }^{15,16}$. It thus makes more sense to assume the kinetics to be cubic. Nevertheless, in order to compare our results with other published results on more conventional alloys, a parabolic law was chosen to evaluate corresponding parabolic rate constants $\left(\mathrm{k}_{\mathrm{p}}\right)$. The obtained values of the parabolic rate constant are given at different temperatures for $\mathrm{Ti}_{3} \mathrm{AlC}_{2}$ and $\mathrm{Ti}_{3} \mathrm{Al}_{0.8} \mathrm{Sn}_{0.2} \mathrm{C}_{2}$ in table 1. A comparison of the oxidation kinetics of $\mathrm{Ti}_{3} \mathrm{AlC}_{2}$ and $\mathrm{Ti}_{3} \mathrm{Al}_{0.8} \mathrm{Sn}_{0.2} \mathrm{C}_{2}$ shows that the parabolic rate constants of $\mathrm{Ti}_{3} \mathrm{Al}_{0.8} \mathrm{Sn}_{0.2} \mathrm{C}_{2}$ are, at the same temperatures, 2-4 orders of magnitude greater than those of $\mathrm{Ti}_{3} \mathrm{AlC}_{2}$. Such a result demonstrates that $\mathrm{Ti}_{3} \mathrm{AlC}_{2}$ has better oxidation resistance than $\mathrm{Ti}_{3} \mathrm{Al}_{0.8} \mathrm{Sn}_{0.2} \mathrm{C}_{2}$. Figure 5 shows the Arrhenius plot of $\mathrm{k}_{\mathrm{p}}$ versus the inverse of temperature. For both materials, a linear fit is obtained. The slope of the straight line allows calculating the apparent activation energies which are 69 and $336 \mathrm{~kJ} . \mathrm{mol}^{-1}$ for $\mathrm{Ti}_{3} \mathrm{AlC}_{2}$ and $\mathrm{Ti}_{3} \mathrm{Al}_{0.8} \mathrm{Sn}_{0.2} \mathrm{C}_{2}$ respectively. Such a slope can be referred to a true activation energy only in cases where the rate-controlling step is well defined, unique and controlled by diff usion through the oxide scale. It may be the case for the fine-grained $\mathrm{Ti}_{3} \mathrm{AlC}_{2}$ where $\mathrm{Al}_{2} \mathrm{O}_{3}$ is the main formed oxide (see figure $8 \mathrm{~b}$ and 9) however, it is unlikely the case for the solid solution. Thus, the slope of the straight line refers to an apparent activation energy. The apparent activation energy determined for the fine-grained $\mathrm{Ti}_{3} \mathrm{AlC}_{2}$ sample is smaller than the ones that have been published previously (in the range 136-258 $\mathrm{kJ} \cdot \mathrm{mol}^{-1}$ ) $11,17,18$. Thus, the apparent activation energy that is obtained for our fine-grained $\mathrm{Ti}_{3} \mathrm{AlC}_{2}$ specimens $\left(69 \mathrm{~kJ} . \mathrm{mol}^{-}\right.$ ${ }^{1}$ ) implies that the first stages of oxidation, which allows alumina formation, is easier than the ones implied for fine-grained $\mathrm{Ti}_{3} \mathrm{Al}_{0.8} \mathrm{Sn}_{0.2} \mathrm{C}_{2}$. One has also to notice that the parabolic rate constants are less temperature dependent for the former specimens.

Figure 6 shows a cross-section view of the oxide layer observed by SEM on the $\mathrm{Ti}_{3} \mathrm{AlC}_{2}$ SPSed specimen oxidized during $1000 \mathrm{~h}$ at $1000^{\circ} \mathrm{C}$. Ti, Al, C and $\mathrm{O}$ corresponding EDXS maps of the oxide layer are once more presented. After $1000 \mathrm{~h}$ of oxidation, the thickness of the oxide layer, mainly composed of $\mathrm{Al}_{2} \mathrm{O}_{3}$, is about $3 \mu \mathrm{m}$. Some nodules of $\mathrm{TiO}_{2}$ are observed on top of 
the $\mathrm{Al}_{2} \mathrm{O}_{3}$ layer. Such a microstructure of the oxide scale has been observed in a lot of works $^{11,12,15,19 \mathrm{c}, 19 \mathrm{~d}, 19 \mathrm{e}}$ and is characteristic of a $\mathrm{Ti}_{3} \mathrm{AlC}_{2}$ with a good oxidation resistance ${ }^{15}$. The $\mathrm{Al}_{2} \mathrm{O}_{3}$ layer effectively inhibited the oxidation, the scale being dense and adherent; carbon is not detected in the oxide layer. As demonstrated by Rao et al. ${ }^{19 e}, \alpha-\mathrm{Al}_{2} \mathrm{O}_{3}$ nuclei nucleate on the $\mathrm{Ti}_{3} \mathrm{AlC}_{2}$ matrix and grow in the initial stage of oxidation, forming the inner $\mathrm{Al}_{2} \mathrm{O}_{3}$ oxide scale. Once the depletion of $\mathrm{Al}$ atoms occurs in the surface layer of $\mathrm{Ti}_{2} \mathrm{AlC}$ matrix, $\mathrm{Ti}$ atoms start to diffuse out and form the outer $\mathrm{TiO}_{2}$ layer.

Figure $7 \mathrm{a}$ and $7 \mathrm{~b}$ show a cross-section view of the oxide layer observed by SEM on the $\mathrm{Ti}_{3} \mathrm{AlC}_{2}$ SPSed specimen oxidized for $24 \mathrm{~h}$ (a) and $500 \mathrm{~h}(\mathrm{~b})$ at $800^{\circ} \mathrm{C}$. $\mathrm{Ti}, \mathrm{Al}, \mathrm{C}$ and $\mathrm{O}$ corresponding EDXS maps of the oxide layer are also presented. After $24 \mathrm{~h}$ of oxidation, the thickness of the oxide layer is about $7 \mu \mathrm{m}$, on top of the $\mathrm{Ti}_{3} \mathrm{AlC}_{2}$ phase, the oxide layer consists in a mixture of $\mathrm{Al}_{2} \mathrm{O}_{3}$ and $\mathrm{TiO}_{2}$. After $500 \mathrm{~h}$ of oxidation, the thickness of the oxide layer is about $20 \mu \mathrm{m}$, the layer in contact with the $\mathrm{Ti}_{3} \mathrm{AlC}_{2}$ phase consists in a mixture of $\mathrm{Al}_{2} \mathrm{O}_{3}$ and $\mathrm{TiO}_{2}$, the intermediate layer consists in $\mathrm{Al}_{2} \mathrm{O}_{3}$ and the external layer mainly consists in $\mathrm{TiO}_{2}$. One can also notice that carbon is very likeley present inside the oxide scale. Such a microstructure of the oxide scale has been observed and discussed by Lee and Park ${ }^{19 b}$. The authors have shown, using $\mathrm{Pt}$ marker on the $\mathrm{Ti}_{3} \mathrm{AlC}_{2}$ surface, that $\mathrm{Al}_{2} \mathrm{O}_{3}$ thin layer is primarily formed and that $\mathrm{TiO}_{2}$ nodules are formed on top of the $\mathrm{Al}_{2} \mathrm{O}_{3}$ thin layer by outward diffusion of $\mathrm{Ti}^{4+}$. Song et al. ${ }^{19 \mathrm{~d}}$, noticing that the amount of $\mathrm{TiO}_{2}$ after 0.5 and $80 \mathrm{~h}$ oxidation remains the same, suggest that the $\mathrm{TiO}_{2}$ nodule formation is terminated once a dense and continuous $\mathrm{Al}_{2} \mathrm{O}_{3}$ layer is formed. Lee and park ${ }^{19 \mathrm{~b}}$ demonstrated that the mixed $\left(\mathrm{Al}_{2} \mathrm{O}_{3}+\mathrm{TiO}_{2}\right)$ layer results from the internal oxidation of $\mathrm{Ti}_{3} \mathrm{AlC}_{2}$ down to the thin $\mathrm{Al}_{2} \mathrm{O}_{3}$ layer ; it is formed due to inward diffusion of $\mathrm{O}^{2-}$ when the alumina scale is not dense enough. 
Figure 8 shows a cross-section of the oxide layer observed by SEM on the $\mathrm{Ti}_{3} \mathrm{Al}_{0.8} \mathrm{Sn}_{0.2} \mathrm{C}_{2}$ SPSed specimen oxidized for $30 \mathrm{~h}$ at $850^{\circ} \mathrm{C}$, simultaneously with $\mathrm{Ti}, \mathrm{Al}, \mathrm{C}, \mathrm{O}$ and $\mathrm{Sn}$ corresponding EDXS maps of the oxide layer. The oxide thickness is about $30 \mu \mathrm{m}$. It consists in six layers: the first one, adjacent to the MAX phase, is a mixture of $\mathrm{TiO}_{2}$ and $\mathrm{Al}_{2} \mathrm{O}_{3}$, the second one consits in a tin oxide whose stoechiometry has not been determined due to the proximity of the other oxides (it is nevertheless quite reasonable to assume that the tin oxide consists in $\mathrm{SnO}_{2}$ ), the third layer is also a mixture of $\mathrm{TiO}_{2}$ and $\mathrm{Al}_{2} \mathrm{O}_{3}$, the fourth one is a tin oxide, the fifth one is $\mathrm{Al}_{2} \mathrm{O}_{3}$ and finally the last one consists in $\mathrm{TiO}_{2}$. Some pores are observed inside the oxide scale, mainly at the interface between the external $\mathrm{TiO}_{2}$ layer and the $\mathrm{Al}_{2} \mathrm{O}_{3}$ adjacent layer. It is now well known that, during the oxidation of $\mathrm{Ti}_{3} \mathrm{AlC}_{2}$ and $\mathrm{Ti}_{2} \mathrm{AlC} \mathrm{MAX}$ phases, a protective $\alpha-\mathrm{Al}_{2} \mathrm{O}_{3}$ layer forms first followed by a discontinuous $\mathrm{TiO}_{2}$ layer formed on top after long time of oxidation ${ }^{19 \mathrm{~b}, 19 \mathrm{~d}, 19 \mathrm{e}}$. The lower bond-breaking energy of Al-Ti bonds in the MAX phase is the driving force of this preferential oxidation process. During the oxidation of the $\mathrm{Ti}_{3} \mathrm{Al}_{0.8} \mathrm{Sn}_{0.2} \mathrm{C}_{2}$ solid solution, it is possible that a $\mathrm{SnO}_{2}$ layer forms first. Indeed, ab initio calculations of the Al-Sn substitution predict a cohesive energy reduction of $21.7 \%$ which is supposed to contribute to a reduction in the thermal stability and to an easier mobility of $\mathrm{Sn}$ compared to $\mathrm{Al}$ in the $\mathrm{A}$ planes of the $\mathrm{MAX}^{36}$. Once a first $\mathrm{SnO}_{2}$ layer is formed, a continuous $\alpha-\mathrm{Al}_{2} \mathrm{O}_{3}$ layer forms followed by the formation of the discontinuous $\mathrm{TiO}_{2}$ upper layer. Due to the inward diffusion of oxygen through the grain boundary, the internal oxidation of the solid solution can continue and lead to the multilayered microstructure shown in figure 8 .

After oxidation at $950^{\circ} \mathrm{C}$ for $30 \mathrm{~h}$, the same oxides are formed as shown in figure 9 . The $\mathrm{Al}_{2} \mathrm{O}_{3}$ and $\mathrm{TiO}_{2}$ external layers are mixed at this temperature to form a single layer consisting in a crystallite's mixture of the two oxides. Moreover, the adhesion of the oxide layer seems to be poorer than the one formed at $850^{\circ} \mathrm{C}$; the external $\mathrm{TiO}_{2}, \mathrm{Al}_{2} \mathrm{O}_{3}$ and $\mathrm{SnO}_{2}$ layers are scaled (see 
red arrow in figure 9) whereas microcracks and debonding are observed in the oxide layer and also at the interface between the 312 phase and the oxide layer (see blue arrow in figure 9).

Oxidation tests performed on $\mathrm{Ti}_{3} \mathrm{Al}_{0.8} \mathrm{Sn}_{0.2} \mathrm{C}_{2}$ solid solution demonstrate the harmful effect of Al substitution by $\mathrm{Sn}$ atoms. Although the tin oxide formation is thermodynamically less favourable than the $\mathrm{Al}_{2} \mathrm{O}_{3}$ or $\mathrm{TiO}_{2}$ ones, the atomic position of tin atoms in the hexagonal structure of the MAX phase (in the A planes) and the weak M-A bonds lead to an easy outward diffusion of $\mathrm{Sn}$ (and $\mathrm{Al}$ ) atoms to the interfaces (oxide/air, MAX/oxide). Moreover, a quite large amount of non protective rutile $\mathrm{TiO}_{2}$ is formed on the surface of the $\mathrm{Ti}_{3} \mathrm{Al}_{0.8} \mathrm{Sn}_{0.2} \mathrm{C}_{2}$ solid solution. Such a deleterious $\mathrm{TiO}_{2}$ formation likely results from the $\mathrm{Al} / \mathrm{Ti}$ atom's ratio, about 0.27 in this case, which is far from 0.32. Indeed, Li et al. have shown that, for Al/Ti atom's ratio smaller than 0.32 , aluminum atom supply at the MAX phase/oxide interface is insufficient to inhibit $\mathrm{TiO}_{2}$ growth ${ }^{19}$.

\section{IV-Summary}

Highly pure (secondary phases in the range 2-5 weight $\%$ ) and dense (porosity smaller than 2 vol.\%) $\mathrm{Ti}_{3} \mathrm{AlC}_{2}$ and $\mathrm{Ti}_{3} \mathrm{Al}_{0.8} \mathrm{Sn}_{0.2} \mathrm{C}_{2}$ bulk samples have been synthesized by coupling natural sintering and SPS densification. The PLM method demonstrates that grain size is small (mean equivalent diameters are smaller than $5 \mu \mathrm{m}$ ). Finally, oxidation tests were performed on the $\mathrm{Ti}_{3} \mathrm{AlC}_{2}$ compound and on the $\mathrm{Ti}_{3} \mathrm{Al}_{0.8} \mathrm{Sn}_{0.2} \mathrm{C}_{2}$ solid solution. It is demonstrated that the substitution of $\mathrm{Al}$ atoms by $\mathrm{Sn}$ atoms in the A plane of the MAX phase has a harmful effect on the oxidation resistance. Indeed, the oxidation kinetics is very high for the solid solution compared to the one of the $\mathrm{Ti}_{3} \mathrm{AlC}_{2}$ compound (parabolic rate constant is 3 order of magnitude smaller in the case of $\mathrm{Ti}_{3} \mathrm{AlC}_{2}$ ). The presence of $\mathrm{Sn}$ atoms in the A planes of the solid solution leads to an easy diffusion of Sn atoms out of the MAX phase. As a result, tin oxide, a non- 
protective oxide, is formed. Moreover, $\mathrm{Al} / \mathrm{Ti}$ atom's ratio being small, non-protective rutile$\mathrm{TiO}_{2}$ is also formed. The oxide layer, on top of the $\mathrm{Ti}_{3} \mathrm{Al}_{0.8} \mathrm{Sn}_{0.2} \mathrm{C}_{2}$ solid solution thus consists in $\mathrm{TiO}_{2}, \mathrm{SnO}_{2}$ and $\mathrm{Al}_{2} \mathrm{O}_{3}$. On the opposite, the oxide layer formed on top of the $\mathrm{Ti}_{3} \mathrm{AlC}_{2}$ phase mainly consists in a protective $\mathrm{Al}_{2} \mathrm{O}_{3}$ layer; a few $\mathrm{TiO}_{2}$ grains being observed on top of this oxide layer.

Acknowledgements:

The authors acknowledge SAFRAN for the financial support and for E. Drouelle PhD grant. 


\section{References}

${ }^{1} \mathrm{M}$. W. Barsoum, "The $\mathrm{M}_{\mathrm{N}+1} \mathrm{AX}_{\mathrm{N}}$ phases: A new class of solids thermodynamically stable nanolaminates," Progress in Solid State Chemistry, 28[1-4] 201-81(2000).

${ }^{2}$ W. Jeitschko, H. Nowotny and F. Benesovsky, "Kohlen-stoffhaltige ternare Verbindungen (HPhase)," Monatshefte für Chemie, 94[4] 672-76(1963).

${ }^{3}$ W. Jeitschko, H. Nowotny and F. Benesovsky, "Die H-phasen $\mathrm{Ti}_{2} \mathrm{TlC}, \mathrm{Ti}_{2} \mathrm{PbC}, \mathrm{Nb}_{2} \mathrm{InC}$, $\mathrm{Nb}_{2} \mathrm{SnC}$ und $\mathrm{Ta}_{2} \mathrm{GaC}, "$ Monatshefte für Chemie, 95[2] 431-35 (1964).

${ }^{4}$ W. Jeitschko and H. Nowotny, "Die Kristallstructur von $\mathrm{Ti}_{3} \mathrm{SiC}_{2}$-Ein Neuer KomplxcarbidTyp," Monatshefte für Chemie, 98[2] 329-37(1967).

${ }^{5}$ M.W. Barsoum, T. El-Raghy, Synthesis and characterization of a remarkable ceramic: $\mathrm{Ti}_{3} \mathrm{SiC}_{2}$, J. Am. Ceram. Soc., 79 (1996) 1953-1956.

${ }^{6}$ M.W. Barsoum, The $\mathrm{M}_{\mathrm{n}+1} \mathrm{AX}$. Phases : A New Class of Solids, Prog. Solid State Chem. 28 (2000) 201-281.

${ }^{7}$ M.W. Barsoum, MAX Phases: Properties of Machinable Ternary Carbides and Nitrides, in: Wiley VCH, Weinheim, 2013.

${ }^{8} \mathrm{~N}$. V. Tzenov and M. W. Barsoum, "Synthesis and characterization of $\mathrm{Ti}_{3} \mathrm{AlC}_{2}, "$ Journal of the American Ceramic Society, 83[4] 825-32 (2000).

${ }^{9} \mathrm{X}$. H. Wang and Y. C. Zhou, "Microstructure and properties of $\mathrm{Ti}_{3} \mathrm{AlC}_{2}$ prepared by the solidliquid reaction synthesis and simultaneous in-situ hot pressing process," Acta Materialia, 50[12] 3141-49 (2002). 
${ }^{10}$ H. Zhai, Z. Huang, M. Ai, Y. Zhou, Z. Zhang and S. Li, "Tribophysical properties of polycrystalline bulk $\mathrm{Ti}_{3} \mathrm{AlC}_{2}$," Journal of the American Ceramic Society, 88[11] 3270-74 (2005).

${ }^{11} \mathrm{X}$. H. Wang and Y. C. Zhou, "Oxidation behavior of $\mathrm{Ti}_{3} \mathrm{AlC}_{2}$ at $1000-1400^{\circ} \mathrm{C}$ in air," Corrosion Science, 45[5] 891-907 (2003).

${ }^{12} \mathrm{X}$. H. Wang and Y. C. Zhou, "High-temperature oxidation behavior of $\mathrm{Ti}_{2} \mathrm{AlC}$ in air," Oxidation of Metals, 59[3-4] 303-20 (2003).

${ }^{13}$ M. Sundberg, G. Malmqvist, A. Magnusson and T. El-Raghy, "Alumina forming high temperature silicides and carbides," Ceramics International, 30[7] 1899-904 (2004).

${ }^{14}$ M. W. Barsoum, N. Tzenov, A. Procopio, T. El-Raghy and M. Ali, Oxidation of $\mathrm{Ti}_{n+1} \mathrm{AlX}_{\mathrm{n}}$ ( $\mathrm{n}=1-3$ and $\mathrm{X}=\mathrm{C}, \mathrm{N})$ : II. Experimental Results, J. Electrochem. Soc. 148 (8), 2001, 551562.

${ }^{15}$ D. J. Tallman, B. Anasori and M. W. Barsoum, A Critical Review of the Oxidation of $\mathrm{Ti}_{2} \mathrm{AlC}$, $\mathrm{Ti}_{3} \mathrm{AlC}_{2}$ and $\mathrm{Cr}_{2} \mathrm{AlC}$ in Air, Materials Research Letters, 1, 3 (2013) 115-125.

${ }^{16}$ J. L. Smialek, Kinetic Aspects of Ti 2 AlC MAX Phase Oxidation, Oxidation of Metals, 83, 3$4(2015)$ 351-366.

${ }^{17}$ X. W. Xu, Y. Li, B. C. Mei, J. Q. Zhu, H. Liu, and J. Qu, "Study on the Isothermal Oxidation Behavior in Air of $\mathrm{Ti}_{3} \mathrm{AlC}_{2}$ Sintered by Hot Pressing." Science in China Series E: Technological Sciences 49 (5), 2006, 513-20.

${ }^{18}$ X. H. Wang and Y. C. Zhou, "Oxidation Behavior of TiC-Containing $\mathrm{Ti}_{3} \mathrm{AlC}_{2}$ Based Material at 500-900 ${ }^{\circ} \mathrm{C}$ in Air." Materials Research Innovations 7(6), 2003, 381-90.

${ }^{19}$ X. C. Li, Y. H. Qian, L. Zheng, J. J. Xu, and M. S. Li, “Determination of the Critical Content 
of $\mathrm{Al}$ for Selective Oxidation of $\mathrm{Ti}_{3} \mathrm{AlC}_{2}$ at $1100^{\circ} \mathrm{C}$." Journal of the European Ceramic Society 36 (14) 2016, 3311-3318.

${ }^{19 b}$ D. B. Lee, S. W. Park, "High-temperature oxidation of $\mathrm{Ti}_{3} \mathrm{AlC}_{2}$ between 1173 and $1473 \mathrm{~K}$ in air. ", Mater. Sci. Eng A. 434 (2006) 147-154.

${ }^{19 c}$ H. J. Yang, Y. T. Pei, J. C. Rao, J. Th. M. De Hosson, S. B. Li and G. M. Song, "High temperature healing of $\mathrm{Ti}_{2} \mathrm{AlC}$ : On the origin of inhomogeneous oxide scale", Scripta Materialia 65 (2011) 135-138.

${ }^{19 d}$ G. M. Song, V. Schnabel, C. Kwakernaak, S. van der Zwaag, J. M. Schneider and W. G. Sloof, "High temperature oxidation behaviour of $\mathrm{Ti}_{2} \mathrm{AlC}$ ceramic at $1200^{\circ} \mathrm{C} »$, Materials at high temperatures, 29, 3 (2012) 205-209.

${ }^{19 e}$ J. C. Rao, Y. T. Pei, H. J. Yang, G. M. Song, S.B. Li, J. Th. M. De Hosson, TEM study of the initial oxide scales of $\mathrm{Ti}_{2} \mathrm{AlC}$, Acta Materialia 59 (2011) 5216-5223.

${ }^{20}$ M. A. Pietzka and J. C. Schuster, "Summary of constitutional data on the Aluminum-CarbonTitanium system.", Journal of Phase Equilibria, 15[4] (1994) 392-400.

${ }^{21} \mathrm{X}$. Wang and Y. Zhou, "Solid-liquid reaction synthesis of layered machinable $\mathrm{Ti}_{3} \mathrm{AlC}_{2}$ ceramic," Journal of Materials Chemistry, 12[3] (2002) 455-60.

${ }^{22}$ A.G. Zhou, C.A. Wang, Y. Huang, "Synthesis and mechanical properties of $\mathrm{Ti}_{3} \mathrm{AlC}_{2}$ by spark Plasma Sintering”, J. Mater. Sci., 38 (2003) 3111. 
${ }^{23}$ J.Q. Zhu, B.C. Mei, X.W. Xu, J. Liu, "Synthesis of single-phase polycrystalline $\mathrm{Ti}_{3} \mathrm{SiC}_{2}$ and $\mathrm{Ti}_{3} \mathrm{AlC}_{2}$ by hot pressing with the assistance of metallic $\mathrm{Al}$ or Si", Mater. Lett. 58 (2004) 588592.

${ }^{24}$ J. H. Han, S. S. Hwang, D. Lee and S. W. Park, "Synthesis and mechanical properties of $\mathrm{Ti}_{3} \mathrm{AlC}_{2}$ by hot pressing $\mathrm{TiC}_{\mathrm{x}} / \mathrm{Al}$ powder mixture," Journal of the European Ceramic Society, 28[5] 979-88(2008).

${ }^{25}$ W. Zhou, B. Mei, J. Zhu and X. Hong, "Synthesis of high-purity $\mathrm{Ti}_{3} \mathrm{SiC}_{2}$ and $\mathrm{Ti}_{3} \mathrm{AlC}_{2}$ by spark plasma sintering (SPS) technique," Journal of Materials Science, 40[8] 2099-100(2005).

${ }^{26}$ G. Liu, K. Chen, H. Zhou, J. Guo, K. Ren and J. M. F. Ferreira, "Layered growth of Ti 2 AlC and $\mathrm{Ti}_{3} \mathrm{AlC}_{2}$ in combustion synthesis," Materials Letters, 61[3] 779-84(2007).

${ }^{27}$ C. L. Yeh and Y. G. Shen, "Combustion synthesis of $\mathrm{Ti}_{3} \mathrm{AlC}_{2}$ from $\mathrm{Ti} / \mathrm{Al} / \mathrm{C} / \mathrm{TiC}$ powder compacts," Journal of Alloys and Compounds, 466[1-2] 308-13(2008).

${ }^{28}$ C. Peng, C. A. Wang, Y. Song and Y. Huang, "A novel simple method to stably synthesize $\mathrm{Ti}_{3} \mathrm{AlC}_{2}$ powder with high purity," Materials Science and Engineering A, 428[1-2] 5458(2006).

${ }^{29}$ S. B. Li, H. X. Zhai, G. P. Bei, Y. Zhou and Z. L. Zhang, "Formation of $\mathrm{Ti}_{3} \mathrm{AlC}_{2}$ by mechanically induced self-propagating reaction in Ti-Al-C system at room temperature," Materials Science and Technology, 22[6] 667-72(2006).

${ }^{30}$ S. B. Li, H. X. Zhai, G. P. Bei, Y. Zhou and Z. L. Zhang, "Synthesis and microstructure of $\mathrm{Ti}_{3} \mathrm{AlC}_{2}$ by mechanically activated sintering of elemental powders," Ceramics International, 33[2] 169-73(2007). 
${ }^{31}$ J. Zhu, B. Mei, X. Xu and J. Liu, "Synthesis of single-phase polycrystalline $\mathrm{Ti}_{3} \mathrm{SiC}_{2}$ and $\mathrm{Ti}_{3} \mathrm{AlC}_{2}$ by hot pressing with the assistance of metallic $\mathrm{Al}$ or Si," Materials Letters, 58[5] 58892(2004).

${ }^{32}$ M. X. Ai, H. X. Zhai, Y. Zhou, Z. Y. Tao, Z. Y. Huang, Z. L. Zhang and S. B. Li, "Synthesis of $\mathrm{Ti}_{3} \mathrm{AlC}_{2}$ powders using Sn as an additive," Journal of the American Ceramic Society, 89[3] 1114-17(2006).

${ }^{33}$ S. B. Li, W. H. Xiang, H. X. Zhai, Y. Zhou, C. W. Li and Z. L. Zhang, "Formation of a singlephase $\mathrm{Ti}_{3} \mathrm{AlC}_{2}$ from a mixture of $\mathrm{Ti}, \mathrm{Al}$ and $\mathrm{TiC}$ powders with $\mathrm{Sn}$ as an additive," Materials Research Bulletin, 43[8-9] 2092-99(2008).

${ }^{33 b}$ G. P. Bei, V. Gauthier-Brunet, C. Tromas and S. Dubois, "Synthesis, characterization and intrinsic hardness of layered nanolaminate $\mathrm{Ti}_{3} \mathrm{AlC}_{2}$ and $\mathrm{Ti}_{3} \mathrm{Al}_{0.8} \mathrm{Sn}_{0.2} \mathrm{C}_{2}$ solid solution," J. Am. Ceram. Soc., 95[11] 102-107 (2012).

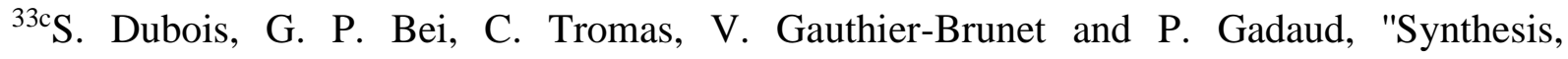
microstructure, and mechanical properties of $\mathrm{Ti}_{3} \mathrm{Sn}_{(1-\mathrm{x})} \mathrm{Al}_{\mathrm{x}} \mathrm{C}_{2}$ MAX phase solid solutions," Inter. J. Appl. Ceram. Tech., 7[6] 719-29(2010).

${ }^{33 d}$ Y. C. Zhou, J. C. Chen, J. Y. Wang, "Strengthening of $\mathrm{Ti}_{3} \mathrm{AlC}_{2}$ by incorporation of Si to form $\mathrm{Ti}_{3} \mathrm{Al}_{1}-\mathrm{Si}_{\mathrm{x}} \mathrm{C}_{2}$ solid solutions.”, Acta Materialia 54(5) (2006) 1317-1322.

${ }^{33}$ X. H. Yin, M. Li, T. P. Li, Y. C. Zhou, "Diffusion Bonding of Ti3AlC2 Ceramic via a Si Interlayer", Journal of Materials Science 42(17):7081-7085.

${ }^{34}$ C. Peng, C. A. Wang, L. Qi and Y. Huang, "Fabrication of $\mathrm{Ti}_{3} \mathrm{AlC}_{2}$ powder with high-purity by pressureless sintering," Materials Science Forum, 475-479 1247-50(2005). 
${ }^{35}$ L. Lutterotti, S. Matthies, and H.-R. Wenk, MAUD: A Friendly Java Program for Material Analysis using Diffraction, IUCr: Newsletter CPD, 21, 1999, 14.

${ }^{36}$ B. Liu, J. Y. Wang, J. Zhang, F. Z. Li, and Y. C. Zhou, "Theoretical Investigation of AElement Atom Diffusion in Ti2AC (A=Sn, Ga, Cd, In, and Pb),” Appl. Phys. Lett., 94 [18] 181906, 3pp (2009). 
Figures captions

Figure 1: XRD patterns obtained on $\mathrm{Ti}_{3} \mathrm{AlC}_{2}$ and $\mathrm{Ti}_{3} \mathrm{Al}_{0.8} \mathrm{Sn}_{0.2} \mathrm{C}_{2}$ SPSed samples.

Figure 2: Back-scattered SEM micrographs of (a) $\mathrm{Ti}_{3} \mathrm{AlC}_{2}$ and (b) $\mathrm{Ti}_{3} \mathrm{Al}_{0.8} \mathrm{Sn}_{0.2} \mathrm{C}_{2}$ SPSed samples.

Figure 3: Weight gain per surface area unit $(\Delta \mathrm{m} / \mathrm{A})$ measured as a function of time at different temperatures and for (a) $\mathrm{Ti}_{3} \mathrm{AlC}_{2}$ and (b) $\mathrm{Ti}_{3} \mathrm{Al}_{0.8} \mathrm{Sn}_{0.2} \mathrm{C}_{2}$ SPSed samples.

Figure 4: (a) $(\Delta \mathrm{m} / \mathrm{A})^{2}$ and (b) $(\Delta \mathrm{m} / \mathrm{A})^{3}$ versus time. Experimental data have been recorded on a $\mathrm{Ti}_{3} \mathrm{AlC}_{2}$ SPSed sample.

Figure 5: Arrhenius plot of the parabolic rate constant as a function of the inverse of temperature for the $\mathrm{Ti}_{3} \mathrm{AlC}_{2}$ (blue squares) and the $\mathrm{Ti}_{3} \mathrm{Al}_{0.8} \mathrm{Sn}_{0.2} \mathrm{C}_{2}$ solid solution (orange circles) SPSed samples. Experimental results from references 11 (red squares), 17 (orange diamond) and 18 (black circles) are also plotted.

Figure 6: Cross-section view of the oxide layer observed by SEM on the $\mathrm{Ti}_{3} \mathrm{AlC}_{2}$ SPSed specimen oxidized during $1000 \mathrm{~h}$ at $1000^{\circ} \mathrm{C}$. Ti, $\mathrm{Al}, \mathrm{C}$ and $\mathrm{O}$ corresponding EDXS maps of the oxide scale. A schematic representation of the different oxide's layer is also given.

Figure 7: Cross-section view of the oxide layer observed by SEM on the $\mathrm{Ti}_{3} \mathrm{AlC}_{2}$ SPSed specimen oxidized during $24 \mathrm{~h}$ (a) and $500 \mathrm{~h}$ (b) at $800^{\circ} \mathrm{C}$. Ti, Al, C and $\mathrm{O}$ corresponding EDXS maps of the oxide scale. A schematic representation of the different oxide's layer is also given.

Figure 8: Cross-section view of the oxide layer observed by SEM on the $\mathrm{Ti}_{3} \mathrm{Al}_{0.8} \mathrm{Sn}_{0.2} \mathrm{C}_{2}$ SPSed specimen oxidized during $30 \mathrm{~h}$ at $850^{\circ} \mathrm{C}$. Ti, Al, C, O and $\mathrm{Sn}$ corresponding EDXS maps of the oxide scale. A schematic representation of the different oxide's layer is also given. 
Figure 9: Cross-section view of the oxide layer observed by SEM on the $\mathrm{Ti}_{3} \mathrm{Al}_{0.8} \mathrm{Sn}_{0.2} \mathrm{C}_{2}$ SPSed specimen oxidized during $30 \mathrm{~h}$ at $950^{\circ} \mathrm{C}$. The red arrow shows that the external $\mathrm{TiO}_{2}, \mathrm{Al}_{2} \mathrm{O}_{3}$ and $\mathrm{SnO}_{2}$ layers are scaled whereas the blue arrow shows microcracks and debonding inside the oxide layer. 


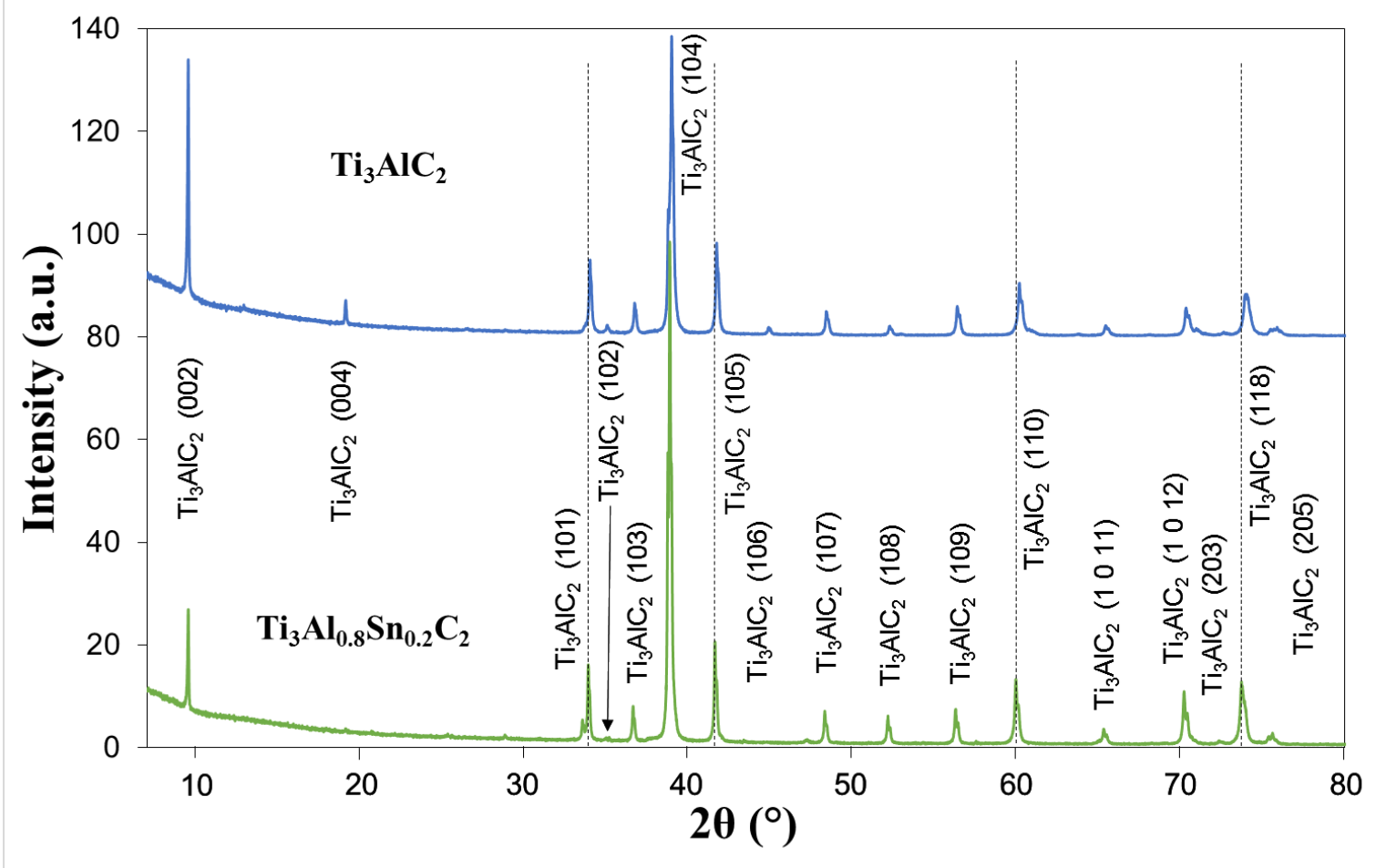

Figure 1: XRD patterns recorded on $\mathrm{Ti}_{3} \mathrm{AlC}_{2}$ and $\mathrm{Ti}_{3} \mathrm{Al}_{0.8} \mathrm{Sn}_{0.2} \mathrm{C}_{2}$ SPSed samples. 

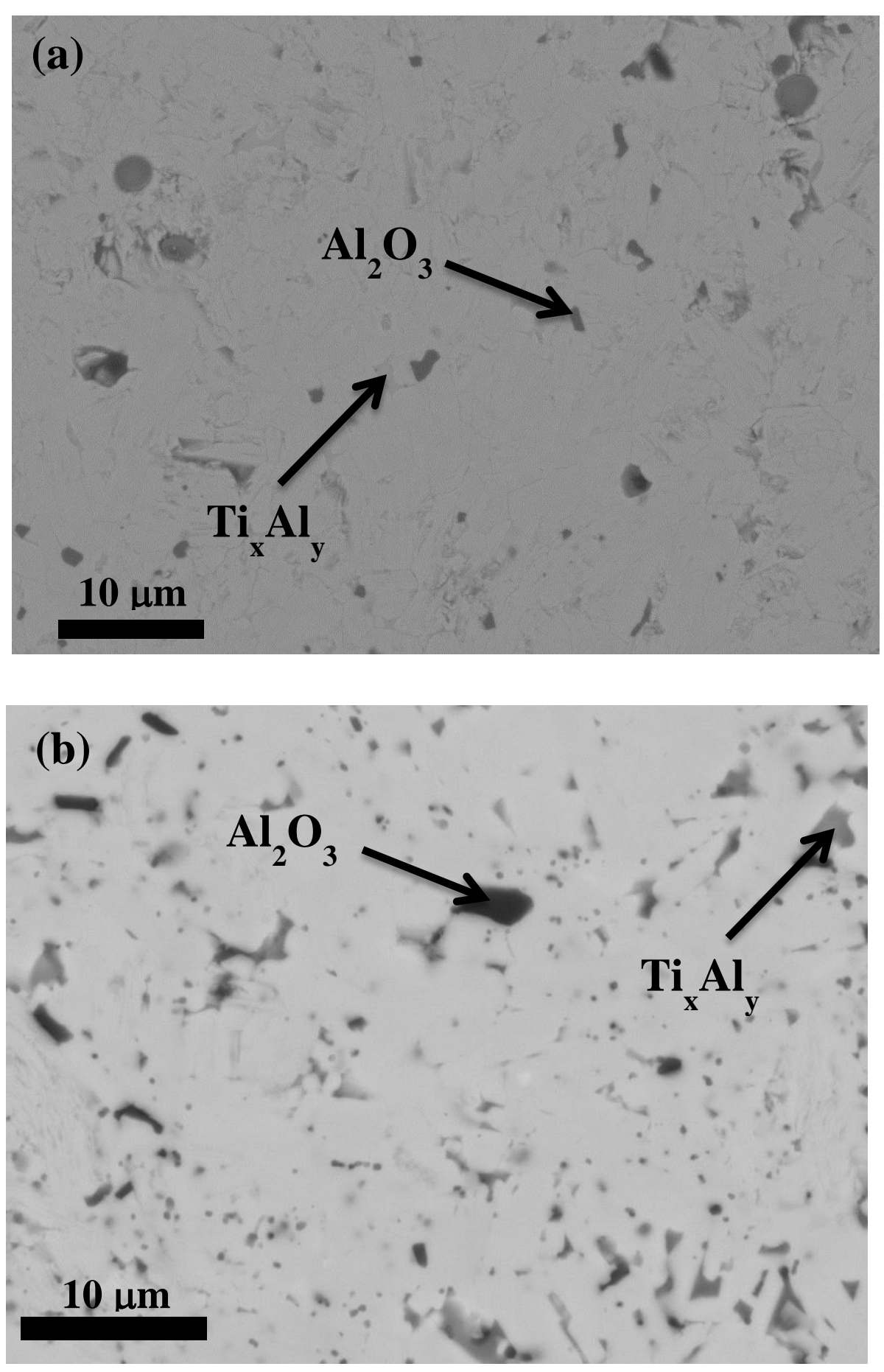

Figure 2: Back-scattered SEM image of (a) $\mathrm{Ti}_{3} \mathrm{AlC}_{2}$ and (b) $\mathrm{Ti}_{3} \mathrm{Al}_{0.8} \mathrm{Sn}_{0.2} \mathrm{C}_{2}$ SPSed samples. 

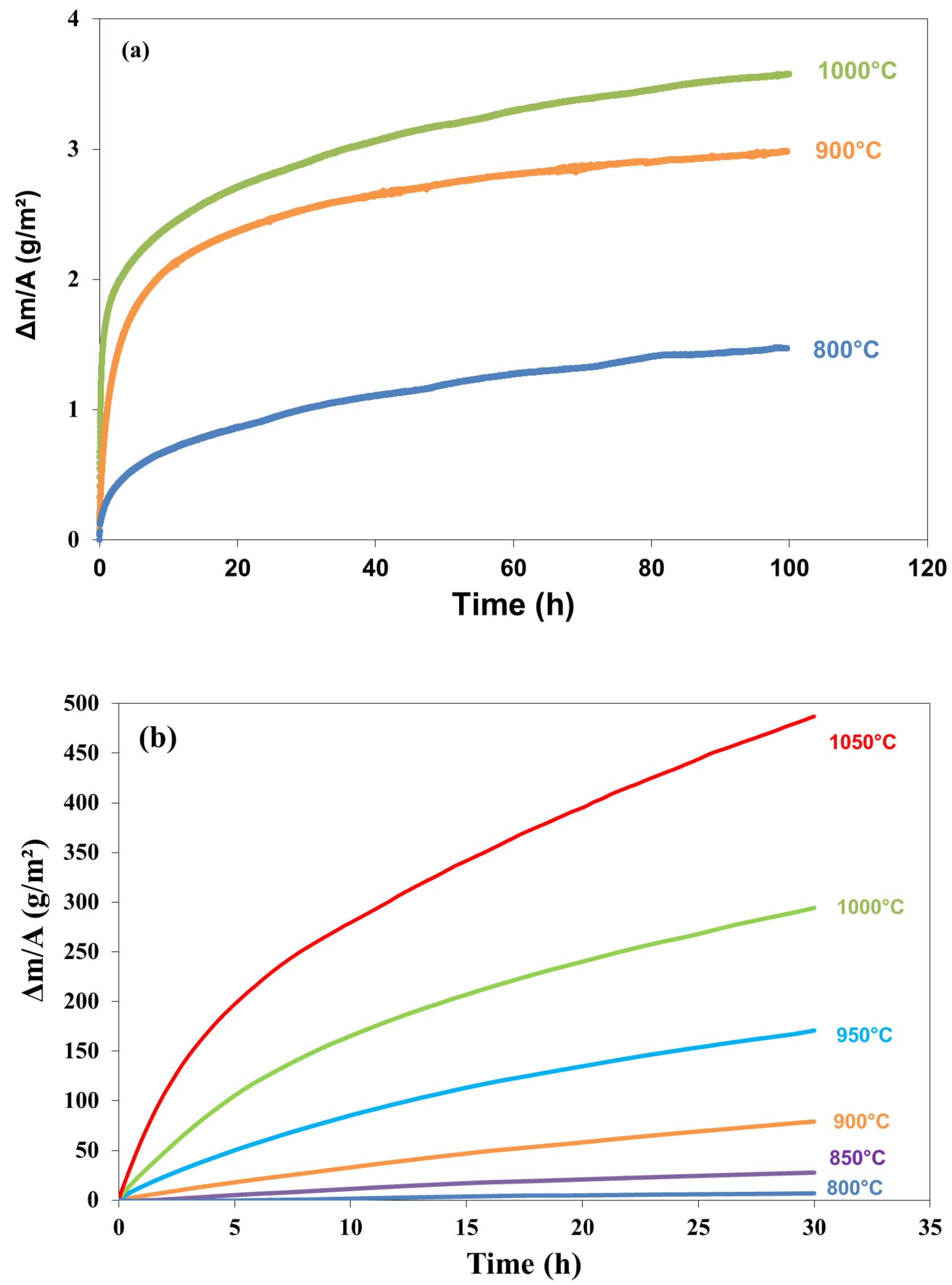


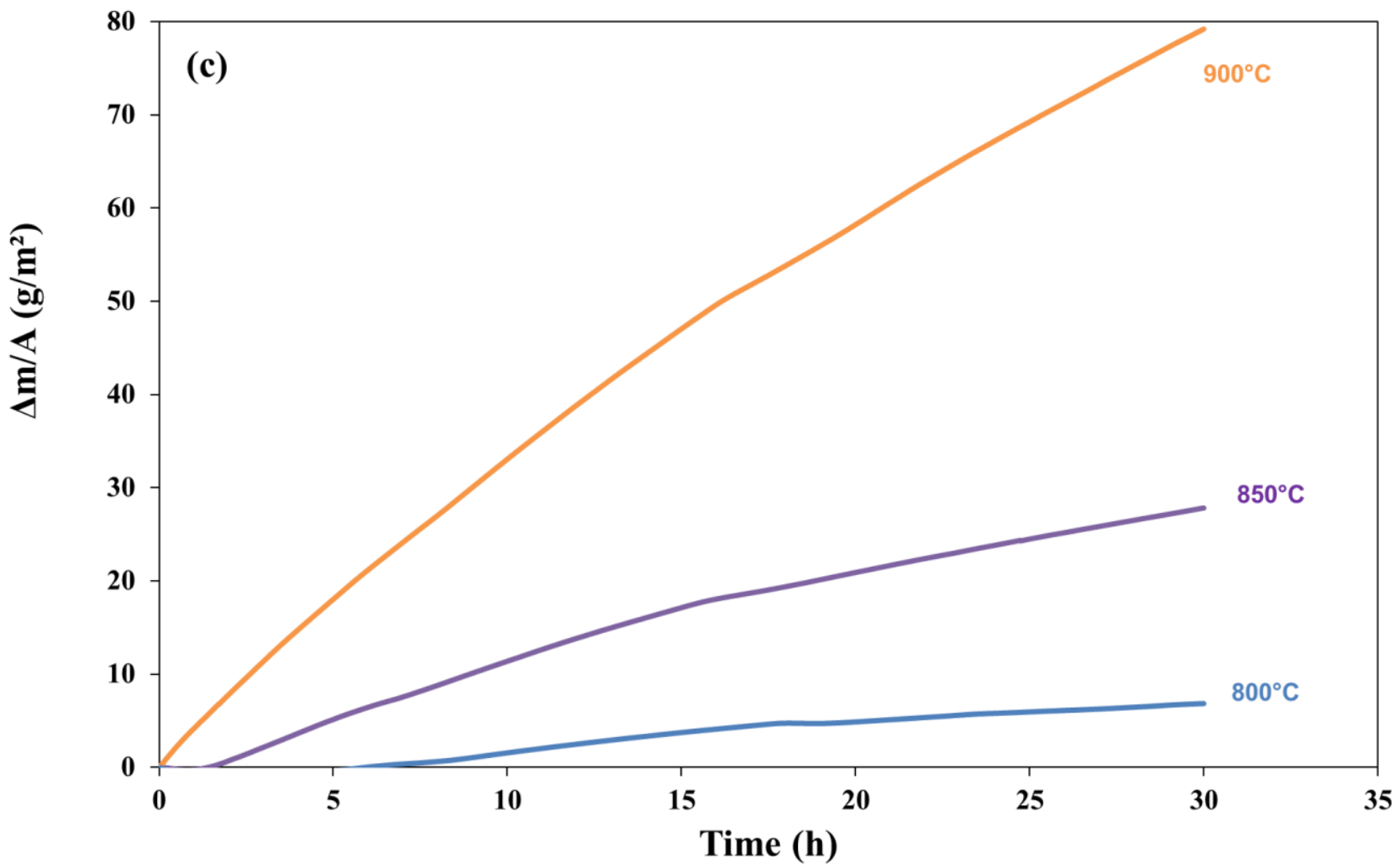

Figure 3: Weight gain per surface area unit $(\Delta \mathrm{m} / \mathrm{A})$ measured as a function of time at different temperatures and for (a) $\mathrm{Ti}_{3} \mathrm{AlC}_{2}$ and (b) $\mathrm{Ti}_{3} \mathrm{Al}_{0.8} \mathrm{Sn}_{0.2} \mathrm{C}_{2}$ SPSed samples. 

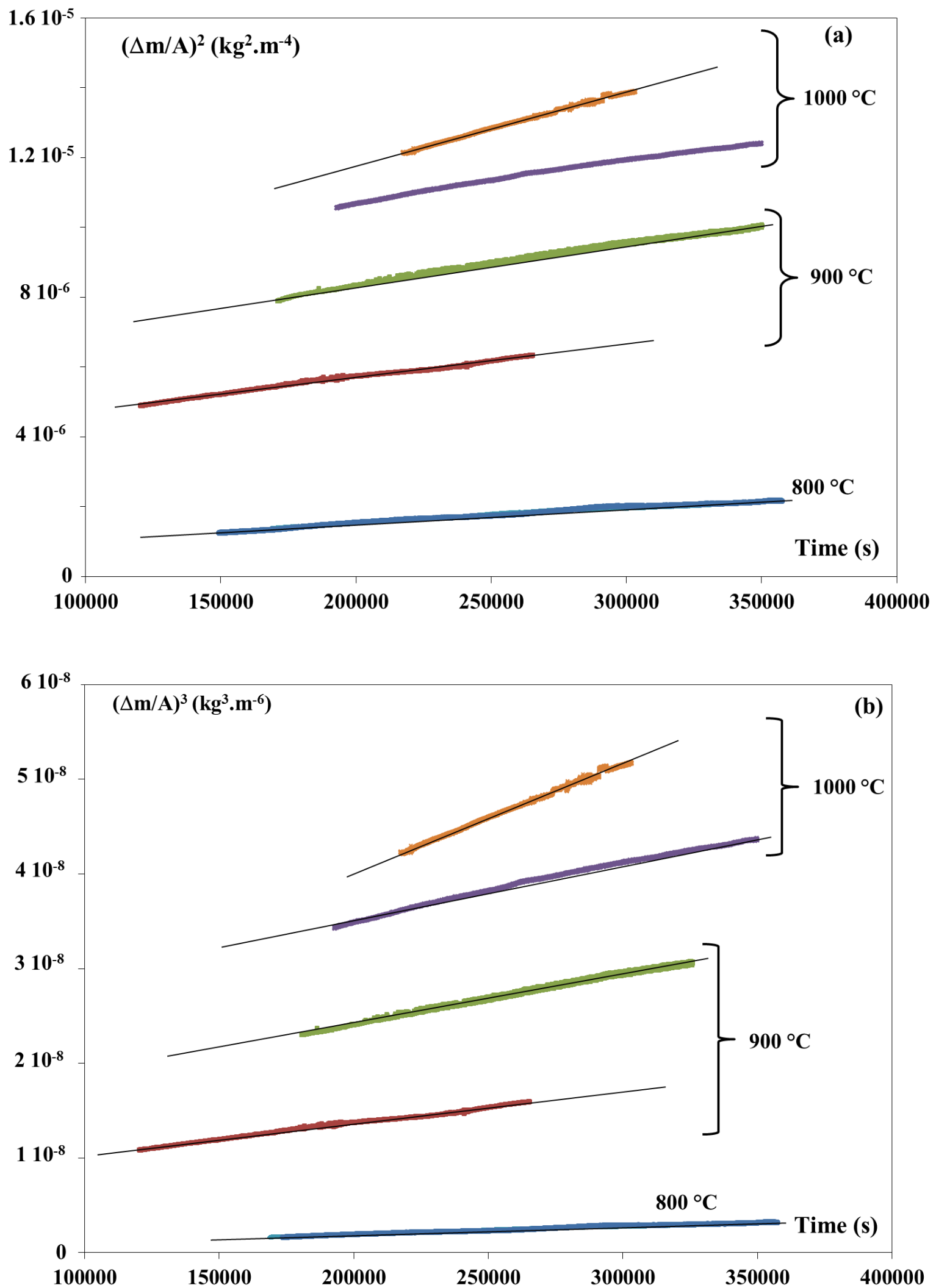

Figure 4: (a) $(\Delta \mathrm{m} / \mathrm{A})^{2}$ and (b) $(\Delta \mathrm{m} / \mathrm{A})^{3}$ versus time. Experimental data have been recorded on a $\mathrm{Ti}_{3} \mathrm{AlC}_{2}$ SPSed sample. 


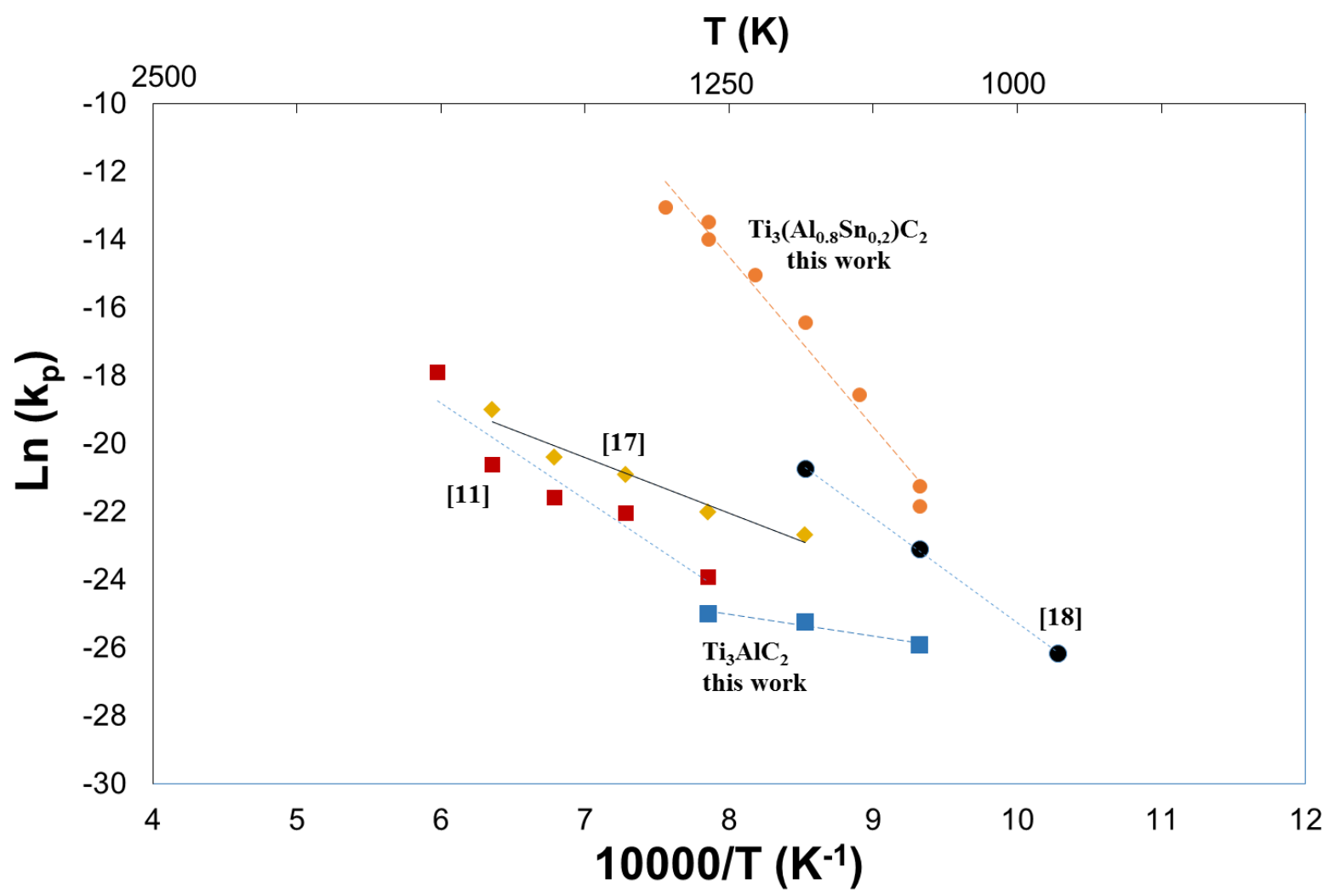

Figure 5: Arrhenius plot of the parabolic rate constant as a function of the inverse of temperature for the $\mathrm{Ti}_{3} \mathrm{AlC}_{2}$ (blue squares) and the $\mathrm{Ti}_{3} \mathrm{Al}_{0.8} \mathrm{Sn}_{0.2} \mathrm{C}_{2}$ solid solution (orange circles) SPSed samples. Experimental results from references 11 (red squares), 17 (orange diamond) and 18 (black circles) are also plotted. 

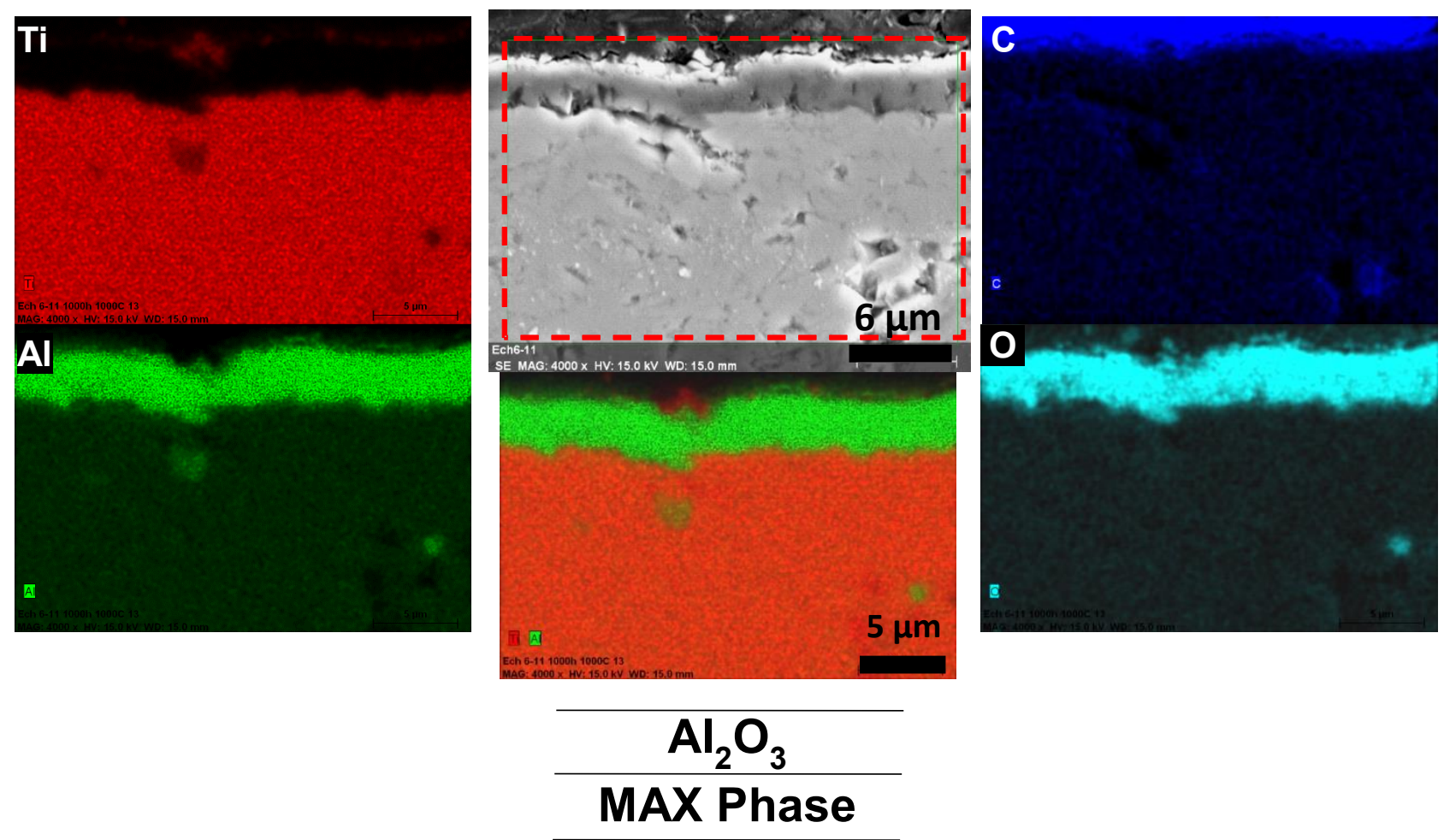

Figure 6 : Cross-section view of the oxide layer observed by SEM on the $\mathrm{Ti}_{3} \mathrm{AlC}_{2}$ SPSed specimen oxidized during $1000 \mathrm{~h}$ at $1000^{\circ} \mathrm{C}$. $\mathrm{Ti}, \mathrm{Al}, \mathrm{C}$ and $\mathrm{O}$ corresponding EDXS maps of the oxide scale. A schematic representation of the different oxide's layer is also given. 
(a) $800^{\circ} \mathrm{C} 24 \mathrm{~h}$
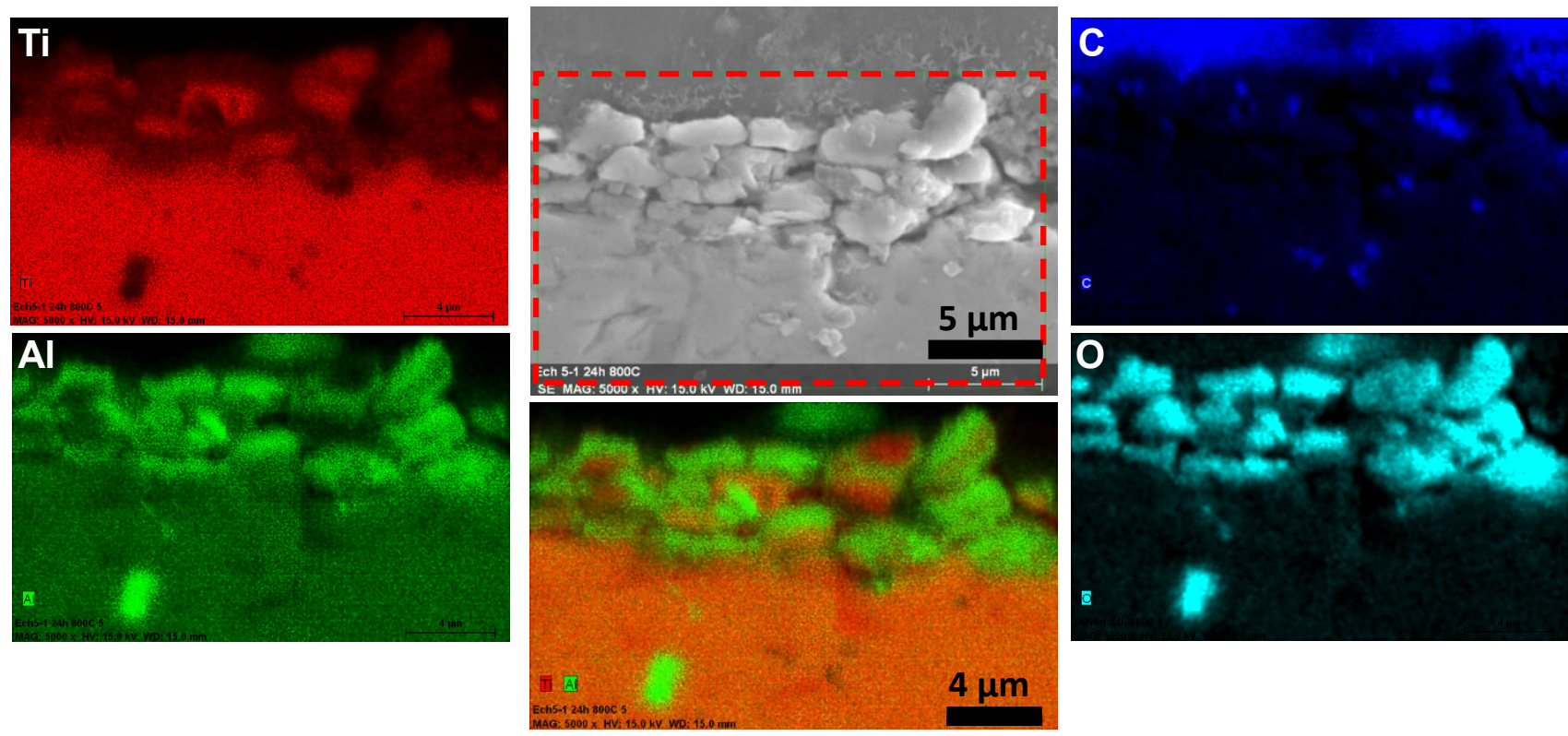

$\frac{\mathrm{TiO}_{2}+\mathrm{Al}_{2} \mathrm{O}_{3}}{\text { MAX Phase }}$

(b) $800^{\circ} \mathrm{C} 500 \mathrm{~h}$
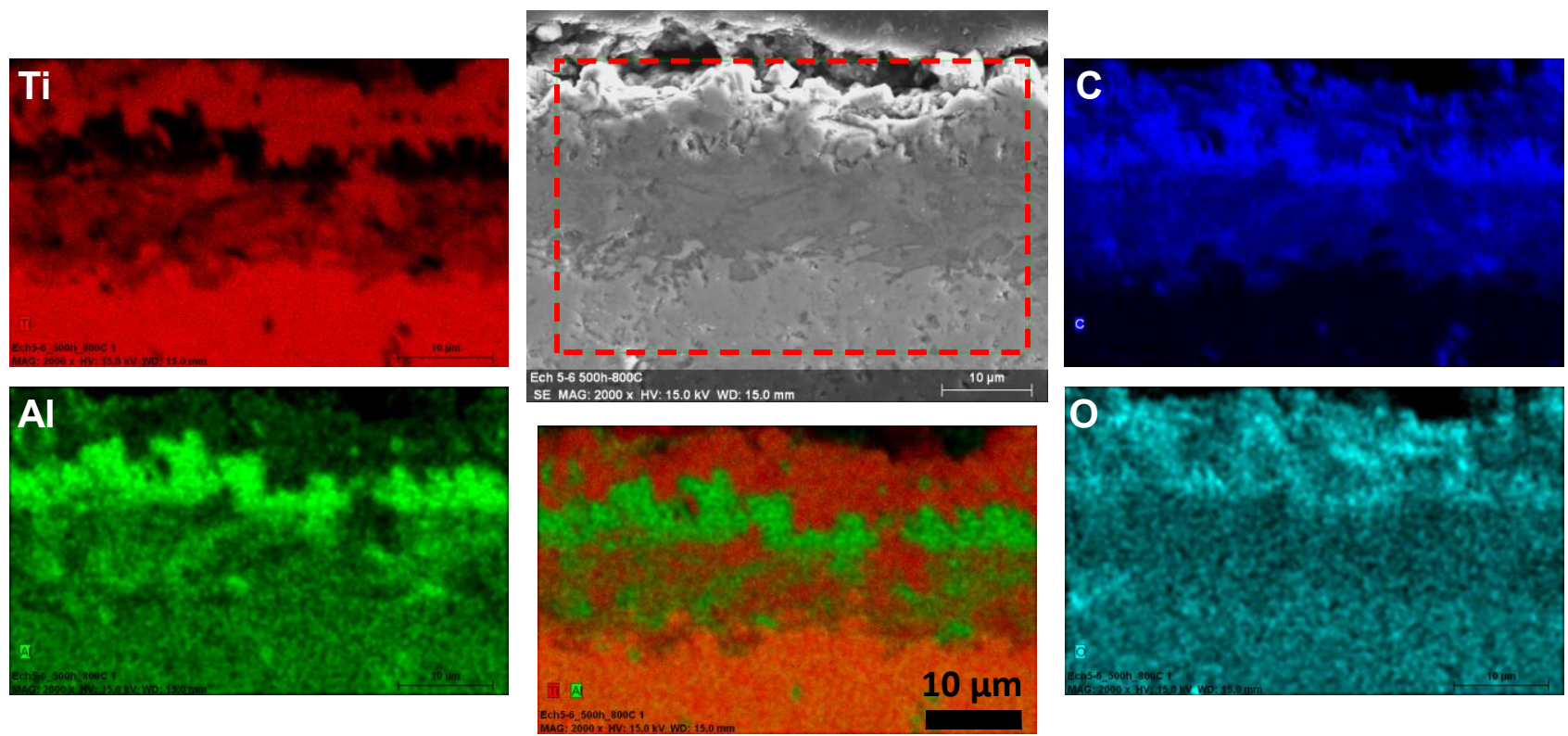

$$
\begin{array}{r}
\mathrm{TiO}_{2} \\
\mathrm{Al}_{2} \mathrm{O}_{3}
\end{array}
$$

$\mathrm{TiO}_{2}+\mathrm{Al}_{2} \mathrm{O}_{3}$

MAX Phase 
Figure 7 : Cross-section view of the oxide layer observed by SEM on the $\mathrm{Ti}_{3} \mathrm{AlC}_{2}$ SPSed specimen oxidized during $24 \mathrm{~h}$ (a) and $500 \mathrm{~h}$ (b) at $800^{\circ} \mathrm{C}$. Ti, Al, C and $\mathrm{O}$ corresponding EDXS maps of the oxide scale. A schematic representation of the different oxide's layer is also given. 

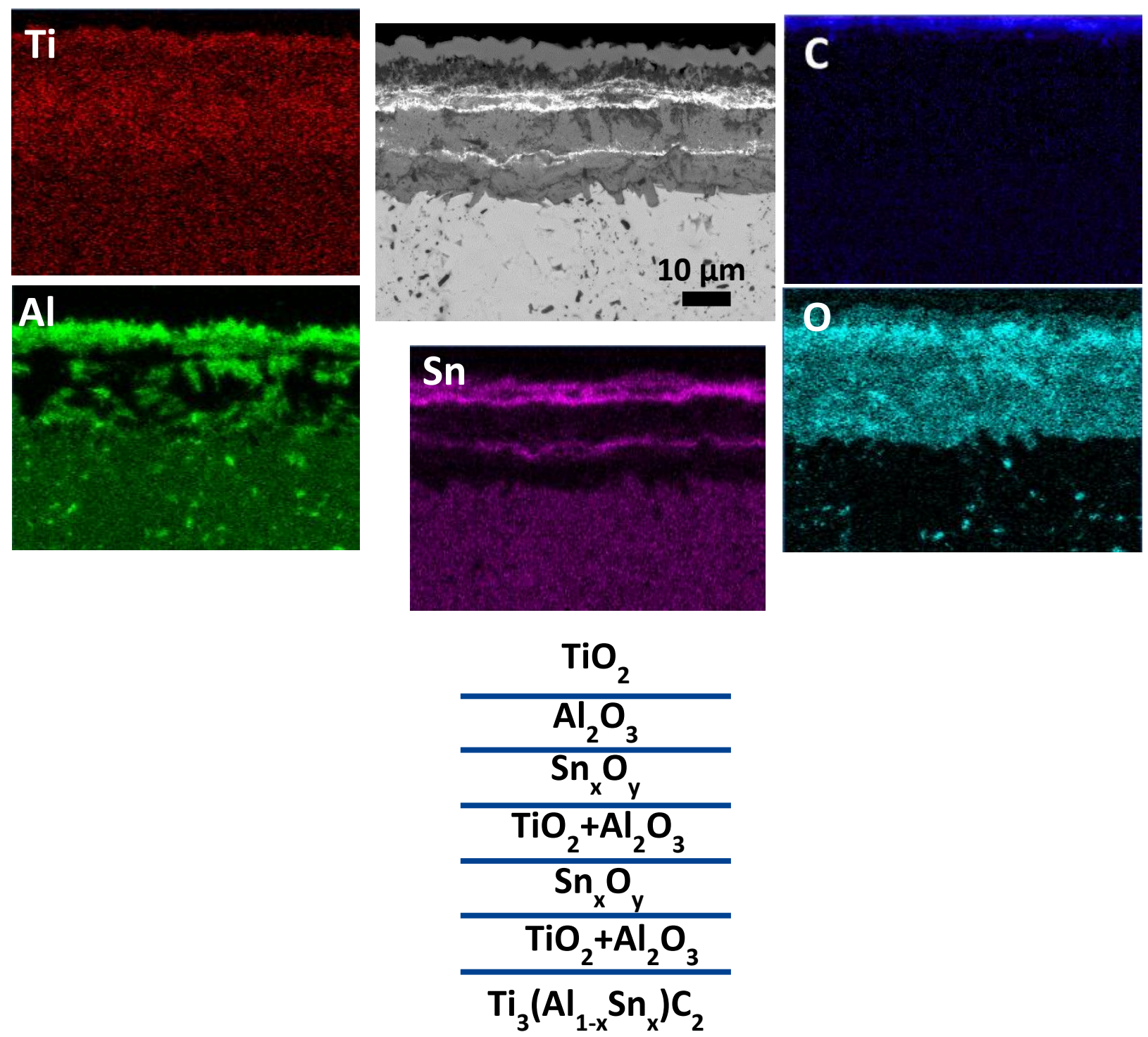

Figure 8: Cross-section view of the oxide layer observed by SEM on the $\mathrm{Ti}_{3} \mathrm{Al}_{0.8} \mathrm{Sn}_{0.2} \mathrm{C}_{2}$ SPSed specimen oxidized during $30 \mathrm{~h}$ at $850^{\circ} \mathrm{C}$. Ti, Al, C, O and Sn corresponding EDXS maps of the oxide scale. A schematic representation of the different oxide's layer is also given. 


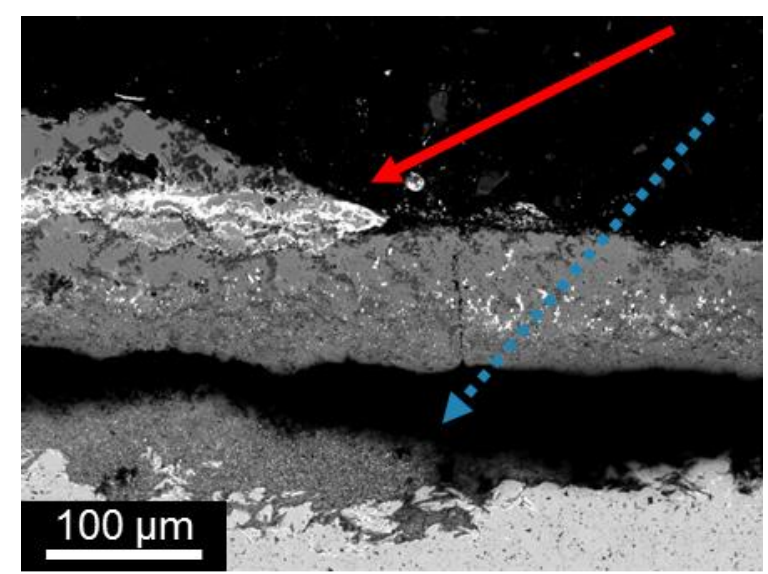

Figure 9: Cross-section view of the oxide layer observed by SEM on the $\mathrm{Ti}_{3} \mathrm{Al}_{0.8} \mathrm{Sn}_{0.2} \mathrm{C}_{2}$ SPSed specimen oxidized during $30 \mathrm{~h}$ at $950^{\circ} \mathrm{C}$. The red arrow shows that the external $\mathrm{TiO}_{2}, \mathrm{Al}_{2} \mathrm{O}_{3}$ and $\mathrm{SnO}_{2}$ layers are scaled whereas the blue arrow shows microcracks and debonding inside the oxide layer. 


\begin{tabular}{|c|c|c|c|c|c|c|c|}
\cline { 3 - 7 } \multicolumn{2}{c|}{} & $800^{\circ} \mathrm{C}$ & $850^{\circ} \mathrm{C}$ & $900^{\circ} \mathrm{C}$ & $950^{\circ} \mathrm{C}$ & $1000^{\circ} \mathrm{C}$ & $1050^{\circ} \mathrm{C}$ \\
\hline \multirow{2}{*}{$\mathrm{k}_{\mathrm{p}}\left(\mathrm{kg}^{2} / \mathrm{m}^{4} / \mathrm{s}\right)$} & $\mathrm{Ti}_{3}\left(\mathrm{Al}_{1-\mathrm{x}} \mathrm{Sn}_{\mathrm{x}}\right) \mathrm{C}_{2}$ & $6,0.10^{-10}$ & $8,8.10^{-9}$ & $7,3.10^{-8}$ & $3,0.10^{-7}$ & $8,4.10^{-7}$ & $2,2.10^{-6}$ \\
\cline { 2 - 8 } & $\mathrm{Ti}_{3} \mathrm{AlC}_{2}$ & $5,6.10^{-12}$ & & $1,1.10^{-11}$ & & $1,4.10^{-11}$ & \\
\hline
\end{tabular}

Table 1 : Kinetic rate constant determined at different temperatures on the $\mathrm{Ti}_{3} \mathrm{Al}_{0.8} \mathrm{Sn}_{0.2} \mathrm{C}_{2}$ and $\mathrm{Ti}_{3} \mathrm{AlC}_{2}$ MAX phase. 